\title{
Comparison of radical-driven technologies applied for paraben mixture degradation: mechanism, biodegradability, toxicity and cost assessment
}

\author{
Marta Gmurek $^{1,2}$ (D) João F. Gomes ${ }^{1}$ - Rui C. Martins ${ }^{1}$ - Rosa M. Quinta-Ferreira ${ }^{1}$
}

Received: 8 April 2019 / Accepted: 7 October 2019/Published online: 20 November 2019

(C) The Author(s) 2019

\begin{abstract}
Parabens (esters of $p$-hydroxybenzoic acid) are xenobiosis belonging to endocrine disruptors and commonly used as a preservative in cosmetics, food, pharmaceutical, and personal care products. Their wide use is leading to their appearance in water and wastewater in the range from $\mathrm{ng} / \mathrm{L}$ to $\mathrm{mg} / \mathrm{L}$. In fact, the toxicity of benzylparaben is comparable to bisphenol $\mathrm{A}$. Therefore, it is important to find not only effective but also ecofriendly methods for their removal from aqueous environment since the traditional wastewater treatment approaches are ineffective. Herein, for the first time, such extended comparison of several radical-driven technologies for paraben mixture degradation is presented. The detailed evaluation included (1) comparison of ozone and hydroxyl peroxide processes; (2) comparison of catalytic and photocatalytic processes (including photocatalytic ozonation); (3) characterisation of catalysts using SEM, XRD, DRS, XPS techniques and BET isotherm; (4) mineralisation, biodegradability and toxicity assessment; and (5) cost assessment. $\mathrm{O}_{3}, \mathrm{H}_{2} \mathrm{O}_{2} / \mathrm{Fe}^{2+}, \mathrm{H}_{2} \mathrm{O}_{2} / \mathrm{UVC}, \mathrm{O}_{3} / \mathrm{H}_{2} \mathrm{O}_{2}, \mathrm{O}_{3} / \mathrm{UVA}, \mathrm{O}_{3} / \mathrm{H}_{2} \mathrm{O}_{2} / \mathrm{UVA}$, UVA/catalyst, $\mathrm{O}_{3} /$ catalyst and $\mathrm{O}_{3} / \mathrm{UVA} /$ catalyst were selected from advanced oxidation processes to degrade parabens as well as to decrease its toxicity towards Aliivibrio fischeri, Corbicula fluminea and Lepidium sativum. Research was focused on the photocatalytic process involving visible light (UVA and natural sunlight) and $\mathrm{TiO}_{2}$ catalysts modified by different metals (Ag, $\left.\mathrm{Pt}, \mathrm{Pd}, \mathrm{Au}\right)$. Photocatalytic oxidation showed the lowest efficiency, while in combining ozone with catalysis and photocatalysis process, degradation efficiency and toxicity removal were improved. Photocatalytic ozonation slightly improved degradation efficiency but appreciably decreased transferred ozone dose (TOD). Results indicate that the degradation pathway is different, or different transformation products (TPs) could be formed, despite that the hydroxyl radicals are the main oxidant.
\end{abstract}

Highlights

- $\mathrm{O}_{3}, \mathrm{H}_{2} \mathrm{O}_{2} / \mathrm{Fe}^{2+}, \mathrm{H}_{2} \mathrm{O}_{2} / \mathrm{UVC}, \mathrm{O}_{3} / \mathrm{H}_{2} \mathrm{O}_{2}, \mathrm{O}_{3} / \mathrm{UVA}, \mathrm{O}_{3} / \mathrm{H}_{2} \mathrm{O}_{2} / \mathrm{UVA}$, UVA/

Cat, $\mathrm{O}_{3} /$ Cat and $\mathrm{O}_{3} / \mathrm{UVA} /$ Cat were compared.

- Noble metal catalysts cause higher effectivity under natural sunlight than under UVA.

- $\mathrm{O}_{3} /$ Cat supported by UVA increases degradation and decreases ozone dose requirements.

- Lower toxicity on different bioindicators after all advanced oxidation processes were observed.

- Combining ozone with catalysis and photocatalysis process improved toxicity removal.

Responsible Editor: Vítor Pais Vilar

Electronic supplementary material The online version of this article (https://doi.org/10.1007/s11356-019-06703-9) contains supplementary material, which is available to authorized users.

Marta Gmurek marta.gmurek@p.lodz.pl

1 Chemical Process Engineering and Forest Products Research Centre (CIEPQPF), Department of Chemical Engineering, Faculty of Sciences and Technology, University of Coimbra, Coimbra, Portugal
2 Faculty of Process and Environmental Engineering, Department of Bioprocess Engineering, Lodz University of Technology, Lodz, Poland 
Keywords Ozonation $\cdot$ Photocatalytic ozonation $\cdot$ Photocatalytic oxidation $\cdot$ Advanced oxidation processes $\cdot$ Paraben $\cdot$ Toxicity

\section{Introduction}

Xenobiotics are organic compounds foreign to living organisms, which do not occur in the form of neither primary nor secondary metabolites. While some xenobiotics are natural compounds, most of them are from anthropogenic source (Hashmi et al. 2017; Yang et al. 2017). They are included in personal protective equipment or pharmaceuticals, referred as pharmaceuticals and personal care products (PPCPs), whose presence in water reservoirs is a serious environmental problem (Yang et al. 2017). The compounds belonging to the PPCP group (e.g. parabens) have different physicochemical properties, which make them difficult to detect and remove from wastewater and natural environment (Nakada et al. 2007; Yang et al. 2017; Wang et al. 2018). Many of xenobiotics have been classified as compounds that disrupt the hormonal balance of the body (xenooestrogenic or endocrine compounds) called endocrine-disrupting compounds (EDCs) (Nakada et al. 2007; Esplugas et al. 2007; Giulivo et al. 2016; Wang and Wang 2016). Numerous studies have confirmed the harmful effect of xenobiotics on disturbing the hormonal balance of organisms, hepatotoxic effects damaging liver cells and the possibility of producing free radicals which cause oxidative stress (Vilela et al. 2018).

Xenobiotics are an interesting research object since they are a group of compounds with significant toxic effects. In addition, in trace amounts, they occur in the aquatic environment. However, even at very low concentrations (ppb or $\mathrm{ppm}$ ), these compounds are dangerous for the environment, and contaminated water causes a threat to people and also affects the condition of animal populations and plants $(\mathrm{Gu}$ et al. 2002). Unfortunately, the still growing consumerism means that the presence of xenobiotics in the lives of people, animals and the environment is inevitable. It is known that the removal of EDCs in wastewater treatment plants using conventional methods is insufficient (Nakada et al. 2007; Esplugas et al. 2007; Wang and Wang 2016; Gmurek et al. 2017; Yang et al. 2017; Wang et al. 2018). Poor efficiency is probably related to physical and chemical properties as well as its toxicity. Considering the product cycle, these compounds in unmetabolised form were found in wastewater, from where they get mainly to water reservoirs (e.g. used pesticides as a result of runoff from agricultural areas get into surface waters). Consequently, they are detected in drinking water from which they can be absorbed into the body.

Parabens (esters of $p$-hydroxybenzoic acid) represent xenobiotics, PPCPs and EDC groups commonly used as preservative in cosmetics and personal care products, food, pharmaceuticals, etc. Although it was found that butylparaben can be synthesised by marine bacteria (Peng et al. 2006), only produced synthetically commercial parabens are used for industrial purpose (Juliano et al. 2017). Furthermore, for the last 10 years, the EU regulation about paraben content in cosmetic products has been restricted. According to Regulation (EU) No. 358/2014 (Juliano et al. 2017), isopropylparaben, isobutylparaben, phenylparaben, benzylparaben and pentylparaben are prohibited in cosmetic products. As reported by Regulation (EU) No. 1004/2014 (Juliano et al. 2017), propylparaben and butylparaben (also their isoforms and salts) were banned from cosmetic products for children under 3 years of age, based on those substances' potential endocrine activity. Additionally, the maximum concentration allowed for these two parabens was reduced in the cosmetic products for adults and kids above 3 years of age (Juliano et al. 2017). Parabens can be considered as endocrine disruptors and carcinogens (Giulivo et al. 2016; Juliano et al. 2017). Moreover, the toxicity and oestrogenicity of benzylparaben is comparable to that of bisphenol A (Martins et al. 2016). Parabens were detected in influents from WWTPs (even at concentrations of $\mathrm{mg} / \mathrm{L}$ ), and after the treatment in effluents, their concentrations were still high (including BzP) (Canosa et al. 2006; Haman et al. 2015; Marta-Sanchez et al. 2018; Gomes et al. 2018a). The presence of paraben was recorded in natural water in Japan, the UK, Portugal, Switzerland, Belgium, China, Spain and the USA in the range of $0.1-676 \mathrm{ng} / \mathrm{L}$ (Jonkers et al. 2010; Haman et al. 2015). Some of them were detected in drinking water in the concentration of $\mathrm{ng} / \mathrm{L}$ in Germany, Spain or the USA (Haman et al. 2015; Marta-Sanchez et al. 2018). Swimming pools are also contaminated by parabens as well as sediments (Haman et al. 2015; Lempart et al. 2018). Due to the characteristics of parabens, which have a negative impact on human and animal populations, a method of their degradation is sought, because nature also fails on removing them through biological process. Moreover, the complex structure causes their insufficient removal in the wastewater treatment process, and as a result of which, they accumulate in living organisms. Until now, commonly applied methods of wastewater treatment or water treatment are ineffective, and a significant amount of these compounds is presented in water. Therefore, it is important to develop efficient methods for eliminating them from wastewater.

Based on literature data, the most effective method of removing them is chemical oxidation using reactive oxygen species generated using ultraviolet (UV) or visible (Vis) radiation or ozone (Nakada et al. 2007; Gottschalk et al. 2010; Nawrocki and Kasprzyk-Hordern 2010; Tay et al. 2010; Gmurek et al. 2015, 2017; Wang and Wang 2016; Pipolo et al. 2017; Gomes et al. 2017a; Wang et al. 2018; 
Foszpańczyk et al. 2018). These methods often allow to obtain products more susceptible to biodegradation. Studies focusing on photodegradation processes of compounds contaminating the aquatic environment are mostly aimed at intensifying the degradation process and obtaining non-toxic phototransformation products. The preferred direction of the development of these methods is the possibility of using renewable energy in the form of solar radiation. Many of the known photochemical methods belong to the group of advanced oxidation processes (AOPs). Lately, AOPs are the most applicable treatment methods for removing hazardous water contaminants, despite that lots of them have a limitation due to optimal $\mathrm{pH}$ parameter. $\mathrm{O}_{3}$ has two pathways of degradation: in acidic $\mathrm{pH}$, direct oxidation via $\mathrm{O}_{3}$, while in alkaline $\mathrm{pH}$, indirect oxidation via ${ }^{\circ} \mathrm{OH}$ (Glaze 1986; Glaze et al. 1987; Lucas et al. 2010). $\mathrm{H}_{2} \mathrm{O}_{2} / \mathrm{Fe}^{2+}$ has an optimum effectivity at $\mathrm{pH} \approx 3$, particularly due to the precipitation of ferric oxyhydroxide at higher $\mathrm{pH}$ value (Ikhlaq et al. 2018, 2019). However, alkaline environment is the favourable $\mathrm{pH}$ for most AOPs (Glaze et al. 1987; Lucas et al. 2010; Xiao et al. 2015; Boczkaj and Fernandes 2017; Shahzad Munir et al. 2019; Asgari et al. 2019; Ikhlaq et al. 2019). In fact, the AOPs are aimed to be applied as tertiary systems for the removal of hazardous water contaminants from municipal wastewater treatment plants (Gmurek et al. 2017; Wang et al. 2018; Miklos et al. 2018; Soriano-Molina et al. 2018). Usually, these effluents are treated in secondary reactors based in biologic systems that require neutral $\mathrm{pH}$ conditions for proper operation. Therefore, it is interesting that the following treatment technologies also operate under those conditions (further $\mathrm{pH}$ adjustment is not necessary) which reduce operating costs, even in case of Fenton process, however, with the disadvantage of iron precipitation (Soriano-Molina et al. 2018). The second important issue in case of AOP is the light source. Unfortunately, the visible light can be applied as an effective light source only for few AOPs. Mostly, they focus on the application of UV radiation with various combinations of other oxidants $\left(\mathrm{H}_{2} \mathrm{O}_{2}, \mathrm{O}_{3}\right.$, Fenton reagent, $\left.\mathrm{TiO}_{2}\right)$. Even though processes using $\mathrm{UV}$ radiation are energy-consuming, these are still widely used due to their high efficiency and rate of degradation process. The use of UV radiation also allows for process control (constant radiation conditions). However, it should be borne in mind that the use of additional oxidants may cause further environmental problems (for example, the resulting sediment during the photo-Fenton process). Thus, processes such as photolysis using $\mathrm{UV}, \mathrm{UV} / \mathrm{H}_{2} \mathrm{O}_{2}, \mathrm{TiO}_{2} / \mathrm{UV}$, $\mathrm{O}_{3} / \mathrm{UV}$ and $\mathrm{TiO}_{2} / \mathrm{O}_{3} / \mathrm{UV}$ can form the foundations of research works using photochemical processes, allowing determination of quantum yields or kinetic constants. Nowadays, the best catalyst is sought; for example, the addition of a second semiconductor will shift the spectrum absorbed by the semiconductor towards the visible light. Moreover, photocatalyst surface modifications by metals are affected by changing the distribution of electrons on the properties of the semiconductor, which increases the photodegradation activity (Nawrocki and Kasprzyk-Hordern 2010; Grabowska et al. 2016; Gmurek et al. 2017; Gomes et al. 2017b; Foszpańczyk et al. 2018).

Bearing in mind the problem associated with parabens, it is important to find not only effective but also ecofriendly methods for their removal from aqueous environment. From all well-known water and wastewater treatment technologies, AOPs are not only important, efficient and ecofriendly but also promising methods that allow to remove persistent aqueous contaminants.

To the best of our knowledge, this is the first time that such extended comparison of several AOPs for the mixture of water pollutant degradation has been presented. The detailed evaluation included (1) comparison of ozone and hydroxyl peroxide processes; (2) comparison of catalytic and photocatalytic processes (including photocatalytic ozonation); (3) characterisation of catalysts using SEM, X-ray diffraction (XRD), DRS, XPS techniques and BET isotherm; (4) mineralisation, biodegradability and toxicity assessment; and (5) cost assessment. $\mathrm{H}_{2} \mathrm{O}_{2} / \mathrm{Fe}^{2+}, \mathrm{H}_{2} \mathrm{O}_{2} / \mathrm{UVC}, \mathrm{O}_{3}, \mathrm{O}_{3} / \mathrm{H}_{2} \mathrm{O}_{2}, \mathrm{O}_{3} / \mathrm{UVA}, \mathrm{O}_{3} /$ $\mathrm{H}_{2} \mathrm{O}_{2} / \mathrm{UVA}$, UVA/catalyst (UVA/Cat), $\mathrm{O}_{3} /$ Cat and $\mathrm{O}_{3} / \mathrm{UVA} /$ catalyst $\left(\mathrm{O}_{3} / \mathrm{UVA} / \mathrm{Cat}\right)$ were selected from AOPs to degrade parabens from aqueous environment. As photocatalysts, noble metals (Pt, $\mathrm{Pd}, \mathrm{Au}, \mathrm{Ag}$ ) that modified $\mathrm{TiO}_{2}$ were applied and compared with pure $\mathrm{TiO}_{2}$. For photocatalytic oxidation, the comparison of UVA light and natural sunlight was made. The toxicity assessment before and after treatment was evaluated by Vibrio fischeri luminescence inhibition and the freshwater Asian clam Corbicula fluminea mortality. Moreover, the phytotoxicity test using Lepidium sativum was performed.

\section{Materials and methods}

\section{Chemicals and reagents}

A solution of five parabens [methylparaben (MP), ethylparaben (EP), propylparaben (PP), butylparaben (BuP) and benzylparaben (BeP)] was used as a model effluent. The pollutant solutions were prepared with Milli-Q (MQ) water using $10 \mathrm{mg} / \mathrm{L}$ of each compound. A commercial form of $\mathrm{TiO}_{2}(\mathrm{P} 25$, crystalline composition of $80 \%$ anatase and $20 \%$ rutile, with a surface area of $50 \mathrm{~m}^{2} / \mathrm{g}$ ) was obtained from Evonik (Germany). 2-Propanol (for analysis) was purchased at Merck (Germany). All solvents [HPLC water (VWR), acetonitrile and formic acid (both from Merck)] were analytical grade $(\geq 99 \%)$. Experimental solutions were prepared using ultrapure water. 


\section{Preparation of photocatalysts}

Two methods of $\mathrm{TiO}_{2}$ modification were used. $\mathrm{TiO}_{2}-\mathrm{Pt}, \mathrm{TiO}_{2}-$ $\mathrm{Pd}$ and $\mathrm{TiO}_{2}-\mathrm{Ag}$ were prepared by $\mathrm{UV}$ reduction of $\mathrm{Pt}^{4+}, \mathrm{Pd}^{2+}$ and $\mathrm{Ag}^{2+}$ used as chloride salts, in the $\mathrm{TiO}_{2}$ (P25) suspension, while $\mathrm{TiO}_{2}-\mathrm{Au}$ was prepared by the sol-gel method, according to Gomes et al. (2017a). In photodeposition method, an aqueous solution of isopropanol containing $\mathrm{H}_{2} \mathrm{PtCl}_{6}(0.5$ wt $\%)$ or $\mathrm{PdCl}_{2}(0.5 \mathrm{wt} \%)$ was degassed with nitrogen and irradiated by UV-Vis light (1000 W Xe lamp) for $6 \mathrm{~h}$. For $\mathrm{TiO}_{2}-\mathrm{Ag}$ preparation, an aqueous solution of ethanol containing $\mathrm{AgNO}_{3}(0.5 \mathrm{wt} \%)$ was degassed with nitrogen and irradiated by UV-Vis light (1000 W Xe lamp) for $100 \mathrm{~min}$. All catalysts prepared by the photodeposition method were separated by centrifugation and dried at $65-120^{\circ} \mathrm{C}$ for $12 \mathrm{~h}$. In the sol-gel method, titanium(IV) isopropoxide (TIP), known as the titanium source for the anatase-type $\mathrm{TiO}_{2}$, was used for $\mathrm{TiO}_{2}$-Au preparation. TIP was mixed with $\mathrm{AuCl}_{4} \mathrm{~K}(0.5 \mathrm{wt} \%)$, methanol and distilled water. The solution was stirred at room temperature for $2 \mathrm{~h}$, followed by a 24-h thermal treatment ( 45 ${ }^{\circ} \mathrm{C}$ ) and calcinations at $400{ }^{\circ} \mathrm{C}$ for $2 \mathrm{~h}$.

\section{Characterisation of photocatalysts}

The microstructural analysis of the surfaces was performed by TESCAN VEGA3 SBH - Easy Probe Scanning Electron Microscopy (SEM) with a tungsten-heated cathode. The SEM images were acquired with a working tension of $5 \mathrm{kV}$, using the secondary electron detector. The optical properties of the photocatalysts were characterised by an ultraviolet/ visible diffuse reflectance spectrophotometer (Evolution 220; Thermo Scientific), in which $\mathrm{BaSO}_{4}$ was employed as the internal reflectance standard. The band gaps for all photocatalysts were determined using the Tauc plot method. The surface areas of catalysts Brunauer-Emmett-Teller were determined using nitrogen $\left(-196^{\circ} \mathrm{C}\right)$ with an accelerated surface area and porosimetry analyser (ASAP 2000, Micrometrics). The crystal structure of photocatalysts was determined from XRD pattern measured in the range of $2 \theta=20$ $80^{\circ}$ using an X-ray diffractometer (X'Pert PRO-MPD, Philips) with $\mathrm{Cu}$ target $(\lambda=1.542 \AA)$. The lattice parameters were estimated by the Le Bail method using FullProf package.

\section{Light sources}

Irradiation experiments were performed using a UVC (254-nm) lamps, UVA (365-nm) lamps and natural sunlight (in Poland as well as in Portugal). Six low-pressure mercury lamps (USHIO, model G8T5 Hg; $7.2 \mathrm{~W}$ each) with a maximum emission of $254 \mathrm{~nm}(88.6 \%)$ were used as a UVC source $\left(E_{0}=1.06 \times 10^{-5}\right.$ $\mathrm{E} / \mathrm{Ls} ; 31.8 \mathrm{~W} / \mathrm{m}^{2}$ ). Three lamps made of blacklight blue glass, which transmits UVA radiation (Philips TL 6 W BLB; tube diameter of $16 \mathrm{~mm}$ ), with the maximum emission of $365 \mathrm{~nm}$ were used as UVA source $\left(E_{0}=5.75 \times 10^{-7} \mathrm{E} / \mathrm{Ls} ; 8.9 \mathrm{~W} / \mathrm{m}^{2}\right)$. The natural sunlight was applied, and the experiments were conducted in the sunny days (in July 2016 and May 2018) with the average irradiance of $340 \mathrm{~W} / / \mathrm{m}^{2}$, corresponding to the photon flux rate $E_{0}=2.60 \times 10^{-4} \mathrm{E} / \mathrm{Ls}$.

The experiments with UVC lamps were carried out in quartz test tubes $(10 \mathrm{~mL}$ and an average optical path length of $0.85 \mathrm{~cm}$ ) placed between two exposure panels using a merry-go-round device.

The experiments with a UVA lamps were carried out in a 2$\mathrm{L}$ reactor with internal lamp source. The experiments with sunlight were carried out in a cylindrical borosilicate reactor $(0.5 \mathrm{~L})$ equipped with a compound parabolic concentrator (CPC) collector. All reactors set up are presented in Fig. S1.

During the experiments, the light exposition was measured with an Oceans Optics USB 4000 fibre optic spectrometer with an approximate resolution of $0.4 \mathrm{~nm}$. All the experiments were performed twice. Results are presented as a mean value of single experiments.

\section{Experimental procedure}

$\mathrm{H}_{2} \mathrm{O}_{2} / \mathrm{Fe}^{2+}$ process

Reaction was carried out in a batch-stirred glass reactor. Ferrous ion $\left(\mathrm{Fe}^{2+}\right)$ was added in the form of iron sulphate, and the reaction started when the desired amount of $\mathrm{H}_{2} \mathrm{O}_{2}$ was injected. $\mathrm{pH}$ was left to run freely (at the beginning, $6 \pm 0.7$, and after $120 \mathrm{~min}$ of reaction, the final $\mathrm{pH}$ value falls to $3.2 \pm 0.3$ ). A detailed procedure and an experimental set-up were previously published in the study of Martins et al. (2016).

\section{$\mathrm{H}_{2} \mathrm{O}_{2} / \mathrm{UVC}$}

The reaction set-up was composed by quartz test tubes (10 $\mathrm{mL}$ ) placed between two exposure panels using a merry-goround device at a distance of $15 \mathrm{~cm}$ from its centre. Each panel was composed by three low-pressure mercury lamps $(7.2 \mathrm{~W}$ each) with a maximum emission for $254 \mathrm{~nm}$. The $\mathrm{pH}$ of the reaction medium was 7 , adjusted by a phosphate buffer. A detailed procedure and an experimental set-up were previously published in the study of Gmurek et al. (2015).

\section{$\mathrm{O}_{3}$-based technology}

Two kinds of equipment were used for ozone-based technology. The first one was a semi-batch reactor of $500 \mathrm{~mL}$ which was used to perform ozonation experiments (single ozonation $\left(\mathrm{O}_{3}\right)$ and $\left.\mathrm{O}_{3} / \mathrm{H}_{2} \mathrm{O}_{2}\right)$. Ozone was produced in situ by an ozone generator that was fed by a pure oxygen stream (99.9\%) supplied by Praxair. Ozone concentration in the gas entering $\left(\left[\mathrm{O}_{3}\right]^{\text {in }}\right)$ and leaving $\left(\left[\mathrm{O}_{3}\right]^{\text {out }}\right)$ the reactor was measured by a gas ozone meter. To ensure chemical regime, the reactor was 
agitated at the approximate speed of $700 \mathrm{rpm}$ by means of a magnetic stirrer. The $\mathrm{pH}$ of the reaction medium was 7 , adjusted by a phosphate buffer. A detailed procedure and an experimental set-up were previously published in the study of Pipolo et al. (2017). The second one was a 2-L glass reactor with the possibility of using 3 UVA lamps which was used for $\mathrm{O}_{3}, \mathrm{O}_{3} / \mathrm{UVA}$, UVA/Cat and $\mathrm{O}_{3} / \mathrm{Cat}_{3} / \mathrm{UVA} / \mathrm{Cat}$ experiments. The stirring speed was previously optimised at $700 \mathrm{rpm}$ to ensure chemical regime. Along the reaction, samples were withdrawn and immediately centrifuged at $3500 \mathrm{rpm}$ to remove the photocatalyst. pH was left to run freely (at the beginning, 5.7). Ozone was produced from pure oxygen stream $(99.9 \%)$, and the inlet $\left(\left[\mathrm{O}_{3}\right]^{\text {in }}\right)$ and outlet $\left(\left[\mathrm{O}_{3}\right]^{\text {out }}\right)$ ozone concentrations were measured by ozone analysers. A detailed procedure and an experimental set-up were previously published (Gomes et al. 2017a, b, c, d).

The photocatalytic experiments were carried out with $0.07 \mathrm{~g} /$ $\mathrm{L}$ of the photocatalyst. To test the adsorption capacity of photocatalyst, it was placed in the reactor with the solution of parabens $5 \mathrm{~min}$ before ozone being fed and turning on the light irradiation. During the degradation experiments, the reactor was bubbled by pure oxygen stream (99.9\%, Praxair, $0.2 \mathrm{~L} / \mathrm{min})$.

All process parameters are collected in Table S1.

\section{Analytical methods}

The concentration of paraben in the mixture was followed by HPLC (UFLC, Shimadzu) with a C18 (SiliaChrom) column at $40{ }^{\circ} \mathrm{C}$. The detection wavelength was $255 \mathrm{~nm}$. The injection volume was $20 \mu \mathrm{L}$, and the mobile phase consisting a mixture of 50:50 methanol:acidic water $(0.1 \%$ orthophosphoric acid) was used with the flow rate of $0.5 \mathrm{~mL} / \mathrm{min}$.

Chemical oxygen demand (COD) was measured according to the standard method 5220D using a calibration curve obtained for potassium hydrogen phthalate (Panreac). The absorbance of the samples was measured at $445 \mathrm{~nm}$ (WTW photoLab S6 photometer) after $2 \mathrm{~h}$ of digestion at $150{ }^{\circ} \mathrm{C}$ (ECO25; VELP Scientifica).

The absorption spectra of parabens were measured in a 1$\mathrm{cm}$ quartz cell on a Unicam spectrophotometer.

\section{Toxicity assessment}

The toxicity assessment was investigated by luminescence inhibition tests with $A$. fischeri using a LUMIStox 300 apparatus. The bioassays with C. fluminea were conducted using adult clams. Before clams were used as a bioindicator, they were maintained at least 1 week under continuous aeration at constant temperature and photoperiod (16-h light and 8-h dark) prior to use. The laboratory culture water was fully renewed once a week. Mortality tests were conducted under static conditions (Gomes et al. 2014). Blank controls with dechlorinated municipal water were applied along with a dilution series of untreated and treated model effluents with exposure lasting $72 \mathrm{~h}$. L. sativum was considered as a bioindicator in the phytotoxicity test. Toxic effects, expressed as germination index (GI), were calculated according to Gomes et al. (2017a). Moreover, the level of the toxic impact on L. sativum was assessed by the method suggested by Wang (1992).

\section{Results}

\section{Preliminary study}

UV radiation is very often used in photodegradation processes. However, the use of UV radiation alone in purification or treatment processes is uneconomical (Gmurek et al. 2017). Most often, monochrome radiation with a wavelength of $254 \mathrm{~nm}$ is used, which, in the case of most organic substances, overlaps with the maximum of their absorbance (Fig. 1). Unfortunately, UVC radiation in this range does not occur in
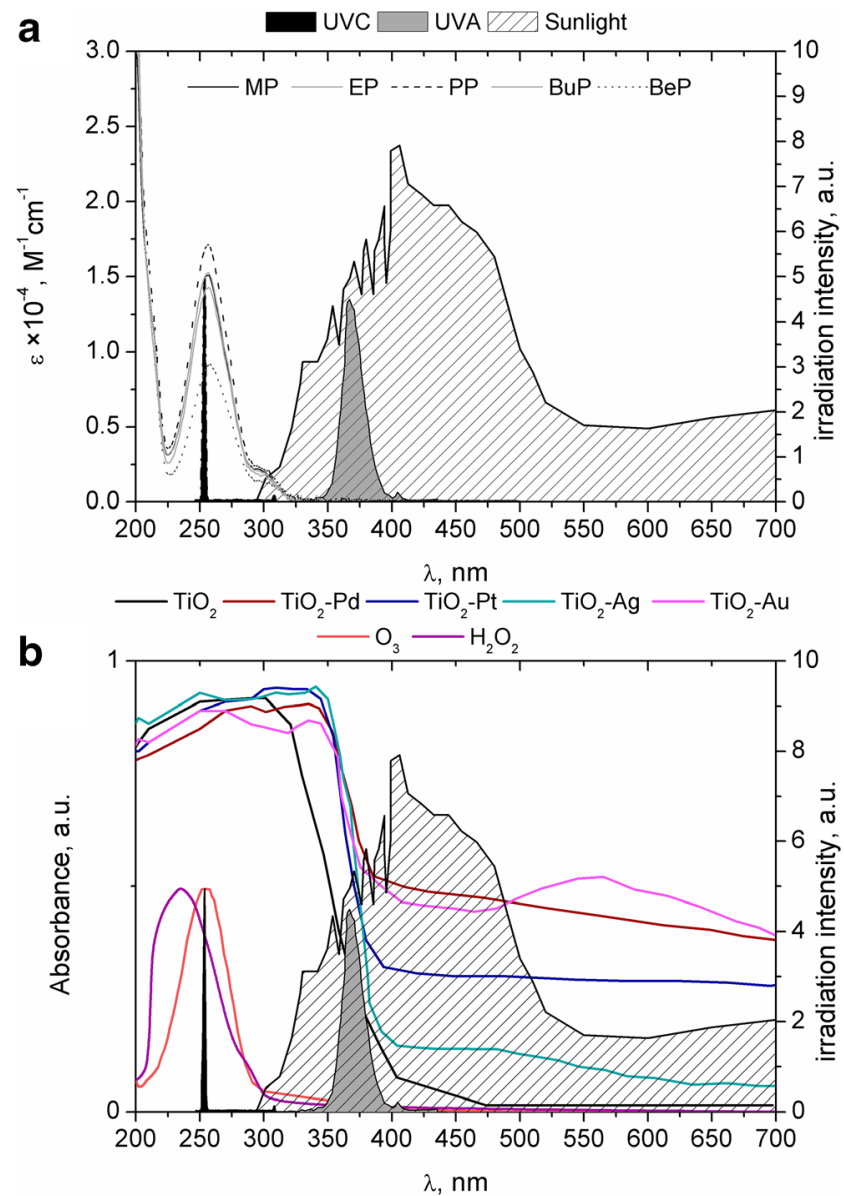

Fig. 1 Absorption spectra of parabens (a) and photocatalysts, ozone and hydrogen peroxide (b) on the background of emission spectra of UVC and UVA lamps as well as sunlight 
the spectrum of solar radiation at the Earth's surface. Thus, studies based on UVC $(254 \mathrm{~nm})$ techniques cannot be directly translated into processes occurring in the natural water environment. Nevertheless, these technologies are still very popular, especially in disinfection systems. Photochemical degradation techniques are also conducted using polychromatic UVA radiation, which falls within the solar spectrum (Fig. 1). Most often, UV radiation is combined with other oxidants, which leads to the generation of hydroxyl radicals $(\cdot \mathrm{OH})$ (Gmurek et al. 2017). It is known that the use of $\bullet \mathrm{OH}$ generated as an oxidant in AOPs leads to very rapid degradation of compounds and high mineralisation. Such high degradation efficiency is obtained as a result of the low selectivity of these oxidants. However, to generate hydroxyl radicals, a lot of energy and an additional oxidiser are needed. On the other hand, the use of less energetic visible radiation is associated with a decidedly lower reaction rate, i.e. a longer photodegradation time. As it was mentioned above, the modification of photocatalysts can improve their photoreactivity in the range of visible light. As can be seen in Fig. 1, all investigated photocatalysts exhibit very strong absorption below $400 \mathrm{~nm}$ that can be explained by the property of titanium to absorb UV light. Above $400 \mathrm{~nm}$ in the visible light region, the best absorption properties have been shown by $\mathrm{TiO}_{2}-\mathrm{Au}$ and $\mathrm{TiO}_{2}-\mathrm{Pd}$, while the worst absorption properties have been shown by $\mathrm{TiO}_{2}-\mathrm{Ag}$. However, all modified photocatalyst are able to absorb visible light, which can be attributed to the surface plasmon resonance of noble metal nanoparticles (Leong et al. 2015; Grabowska et al. 2016).

To evaluate the applicability of photodegradation processes to decontamination of parabens, the direct photolysis of their mixture under UVC and UVA lamps as well as sunlight has been compared. As it was expected, according to the results depicted in Fig. 1, almost complete removal after $1 \mathrm{~h}$ has been achieved when a UVC lamp was used (Fig. S2). Besides, negligible degradation was observed under UVA light, while natural sunlight has not let any degradation at all (Fig. S1).

\section{Comparison of ozone and $\mathrm{H}_{2} \mathrm{O}_{2}$ technologies}

It is well known that the capable action of ozone, $\mathrm{H}_{2} \mathrm{O}_{2}$ and light improves the effectivity of decontamination. However, it should be noticed that the process parameters such as hydrodynamic conditions are significant. The synergetic effects are not always observed; moreover, a scavenging effect can be also expected, while some oxidants are added in extent. Furthermore, the decrease of initial concentrations is useful for the understanding of reaction mechanisms, but it is not sufficient for real effluents containing a mixture of organic compounds and no information is given about degradation of by-products. More detailed information is given by COD removal since the global organic matter removal is followed. As can be seen in Fig. 2, the process parameters are extremely

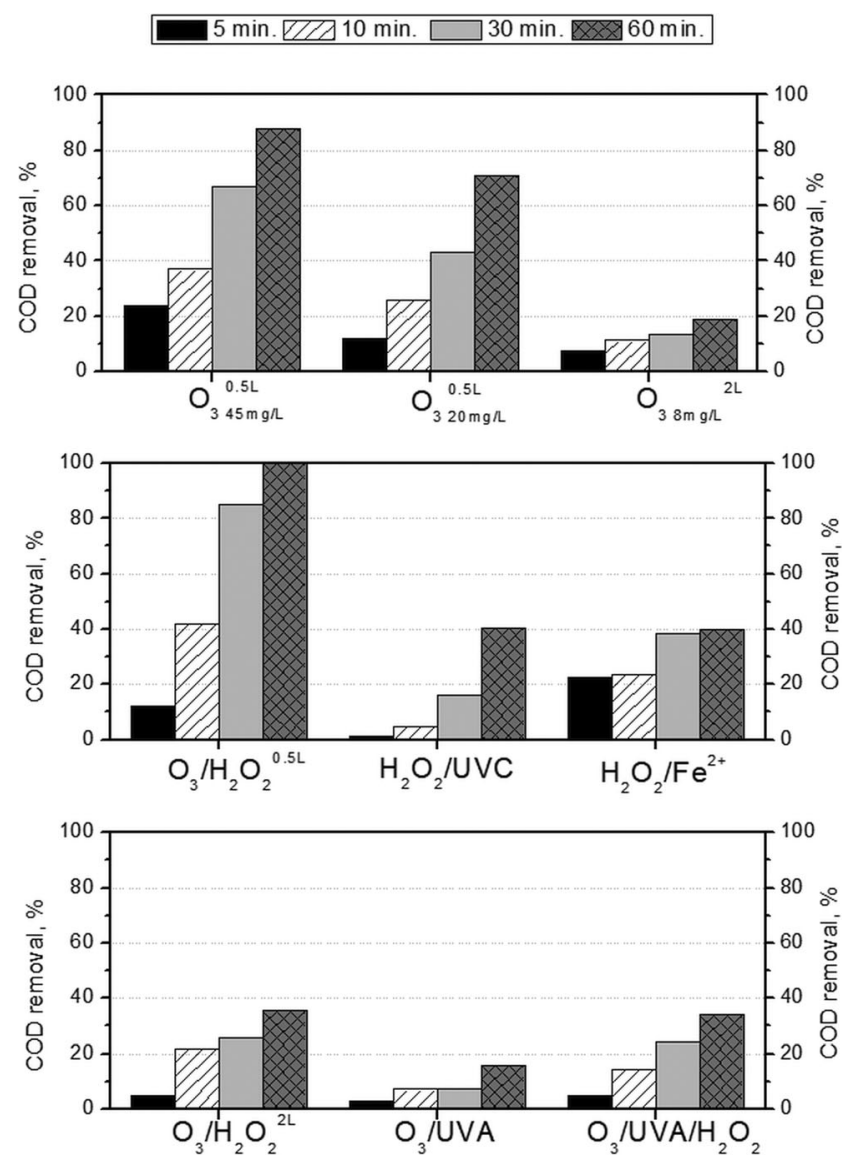

Fig. 2 Comparison of COD removal by different AOPs

important. Although all processes led to complete removal of initial concentration of parabens after $2 \mathrm{~h}$ (mostly resulted in $80 \%$ concentration reduction of parabens after $1 \mathrm{~h}$ ), the COD removal is totally different for all of them.

The efficiency of ozone-based technology is highly dependent on $\mathrm{pH}$, which has the ability to change the ozone oxidation pathway and dissolve ozone concentration (Hoigné and Bader 1976; Olak-Kucharczyk and Ledakowicz 2016; Pipolo et al. 2017; Asgari et al. 2019). In an acidic condition, molecular ozone pathway occurs; in neutral and alkaline environments, the hydroxyl radical pathway is promoted. Furthermore, $\mathrm{O}_{3}$ solubility increased with a decrease in $\mathrm{pH}$ (Bin 2006), affecting ozone concentration in liquid. It is well known that the ozone saturation is dependent not only on temperature but also on $\mathrm{pH}$ which can be effected by liquid constituents or impurities such as salinity and ionic strength (Bin 2006). If the AOP treatment is taken into consideration, two possible situations can occur: it can be supplemented for secondary effluents after biological treatment $(\mathrm{pH}$ close to neutral) or before biological treatment (effluents do not have to be buffered). Therefore, three reaction conditions during single ozonation have been investigated. At buffered neutral condition $(\mathrm{pH} \sim 7)$ in small volume reactor $(500 \mathrm{~mL})$, two ozone inlet gas concentrations were used $(45 \mathrm{mg} \mathrm{O} / \mathrm{L}$ and 
$20 \mathrm{mg} \mathrm{O}_{3} / \mathrm{L}$ ). While in non-buffered solution (2-L reactor), $8 \mathrm{mg} \mathrm{O}_{3} / \mathrm{L}$ was applied. In both cases, the mass transference resistances can be neglected (Gomes et al. 2017c; Pipolo et al. 2017). It is well known that hydroxyl radicals are more reactive than molecular ozone. Second-order rate constants for reaction with ${ }^{\circ} \mathrm{OH}$ are $10^{9}-10^{10} \mathrm{M}^{-1} / \mathrm{s}$ order of magnitude (Tay et al. 2010; Gmurek et al. 2015), while the secondorder rate constants for reaction of organic molecules with ozone are lower $\sim 10^{2}-10^{3} \mathrm{M}^{-1} / \mathrm{s}$ or $\sim 10^{5}-10^{6} \mathrm{M}^{-1} / \mathrm{s}$ in acidic or neutral condition, respectively (Tay et al. 2010; OlakKucharczyk and Ledakowicz 2016). Ozone dose is an important key parameter in determining the residual ozone concentration. However, the ozone decomposition increases with increasing $\mathrm{pH}$. Therefore, at low $\mathrm{pH}$, less ozone concentration is required because ozone lifetime is much longer than in neutral or alkaline environment (Biń 2006; Hansen et al. 2016).

As can be seen in Fig. 2, by single ozonation in buffered solution when the reaction occurs via ${ }^{\circ} \mathrm{OH}$, the $\mathrm{COD}$ removal was much higher than in not buffer solution. At the buffered solution, it was observed that with increasing ozone dosage, the reaction was accelerated. However, in the non-buffered solution, the ozone concentration was much lower, and the increase of it would be meaningless. The ozone pathways will always be slower than ${ }^{\circ} \mathrm{OH}$. In case when the $\mathrm{pH}$ was not adjusted (initial $\mathrm{pH}=5.7$ then decreased during the reaction), even when $\mathrm{H}_{2} \mathrm{O}_{2}$ or UVA was used, the effectivity has not increased significantly (Fig. 2). From integration of ozonation with the biological system point of view, if the initial concentration of contaminants was degraded, higher COD removal is not required, because biological treatment will be able to handle it.

However, application of single ozonation led to the problem of residual $\mathrm{O}_{3}$ in treated wastewater that does not allow for the immediate use of biological treatment after it (the remaining dissolved ozone must be let to be decomposed first before the biological reactor). This disadvantage can be overcome by the merging action of oxidants. It was mentioned that combining $\mathrm{O}_{3}$ with $\mathrm{UV}$ or $\mathrm{H}_{2} \mathrm{O}_{2}$ to enhance $\cdot \mathrm{OH}$ generation is often more effective than $\mathrm{O}_{3}$ alone. The best results have been obtained for $\mathrm{O}_{3} / \mathrm{H}_{2} \mathrm{O}_{2}(0.5 \mathrm{~L})$ treatment when the ${ }^{\circ} \mathrm{OH}$ radical pathways occurred $(\mathrm{pH}=7)$. Even the application of $\mathrm{H}_{2} \mathrm{O}_{2} /$ UVC and Fenton reagent did not give better results (Fig. 2). It should be noticed that in the case of the Fenton process after the addition of iron sulphate and hydrogen peroxide, $\mathrm{pH}$ decreased from neutral to $\mathrm{pH} 3.6$ [optimal condition according to Neyens and Baeyens 2003, Martins et al. 2016 and Ikhlaq et al. 2018]. The synergetic effect of $\mathrm{H}_{2} \mathrm{O}_{2}$ and $\mathrm{O}_{3}$ has been also observed in the case of non-buffered solution (Fig. 2).

The generation of $\bullet \mathrm{OH}$ in $\mathrm{O}_{3} / \mathrm{UV}$ is initiated by the photolysis of $\mathrm{O}_{3}$ by UV (Gottschalk et al. 2010). The application of UVC $(254 \mathrm{~nm})$ enhances the oxidation potential due to the high molar extinction coefficient of $\mathrm{O}_{3}\left(\varepsilon_{254}=3300 \mathrm{M}^{-1} / \mathrm{cm}\right)$ (Gottschalk et al. 2010) (Fig. 1b). However, the major drawback of the ozone-based technology especially $\mathrm{UV} / \mathrm{O}_{3}$ is generating high operational costs (the energy requirement of $\mathrm{O}_{3}$ production and UVC lamp equipment). The cheaper UVA lamp $(365 \mathrm{~nm})$ is not effective as a UVC source, because the ozone molecule is not absorbed in this region, so the $\bullet \mathrm{OH}$ is not effectively produced. Therefore, the COD removal is even lower than in the case of single ozonation (Fig. 2). A better COD removal is achieved when $\mathrm{O}_{3} / \mathrm{H}_{2} \mathrm{O}_{2}$ was applied, especially when effectivity has been considered from the transferred ozone dose (TOD) point of view (Fig. S3). The action of $\mathrm{O}_{3}$ with $\mathrm{H}_{2} \mathrm{O}_{2}$ and UVA led to worse results than $\mathrm{O}_{3} / \mathrm{H}_{2} \mathrm{O}_{2}$ and lower COD removal and required more TOD (Fig. 2, Fig. S3). However, the $\mathrm{O}_{3} / \mathrm{H}_{2} \mathrm{O}_{2} / \mathrm{UVA}$ system exhibited higher COD removal in comparison to single ozonation and $\mathrm{O}_{3} /$ UVA and required less TOD (Fig. 2, Fig. S3). Based on the results, it was shown that the effectivity of the process with respect to time as well as TOD must be considered.

\section{Photocatalytic processes}

As shown in Fig. 1b, the photocatalysts with noble metals like $\mathrm{Pd}, \mathrm{Ag}, \mathrm{Pt}$ and Au effectively absorbed UVA as well as visible light. Moreover, it was proved that both of this light do not cause the photodegradation of parabens directly via photolysis (Fig. S1). $\mathrm{TiO}_{2}-\mathrm{Pd}$ and $\mathrm{TiO}_{2}$-Au exhibit the best absorption characteristics in the visible light range than $\mathrm{TiO}_{2}-\mathrm{Pt}$ and $\mathrm{TiO}_{2}-\mathrm{Ag}$, while $\mathrm{TiO}_{2}$ has the worst ability to absorb visible light (Fig. 1b). That can be attributed to the width of the band gaps as shown in Table 1 and Fig. S4. Indirect/direct band gaps of pure $\mathrm{TiO}_{2}(3.27 \mathrm{eV} / 3.38 \mathrm{eV})$ were reduced to 3.00 $\mathrm{eV} / 3.22 \mathrm{eV}, 2.74 \mathrm{eV} / 3.23 \mathrm{eV}, 2.59 \mathrm{eV} / 3.19 \mathrm{eV}$ and $2.5 \mathrm{eV} /$ $3.13 \mathrm{eV}$ for $\mathrm{TiO}_{2}-\mathrm{Ag}, \mathrm{TiO}_{2}-\mathrm{Pt}, \mathrm{TiO}_{2}-\mathrm{Au}$ and $\mathrm{TiO}_{2}-\mathrm{Pd}$ (all 0.5 wt\%), respectively (Table 1). Since $\mathrm{TiO}_{2}-\mathrm{Pd}$ and $\mathrm{TiO}_{2}-\mathrm{Au}$ have the narrowest and similar band gaps (both direct and indirect), both perform in the Vis light range better, increasing the efficiency of the photocatalysis. The improvement in visible range absorption ability may be attributed to the surface plasmon resonance of noble metal nanoparticles. In Fig. 1b, in visible range, the maximum absorption peak due to localised surface plasmon resonance (LSPR) for $\mathrm{TiO}_{2}-\mathrm{Au}$ and $\mathrm{TiO}_{2}-\mathrm{Ag}$ can be observed (positioned in the range of 525-600 nm and $450-500 \mathrm{~nm}$, respectively). It is well known that the photoactivity has also influenced the particle size, shape and particle distribution. Moreover, the sol-gel method gives ability to synthesise nanosized titania with high purity at low temperature (Xiao et al. 2015), while the photodeposition method allows a better particle size distribution control (Wenderich and Mul 2016). SEM images present the successfully deposited noble metals (Fig. S5). The modification by noble metal resulted in the homogeneous distribution of the $\mathrm{Pd}, \mathrm{Ag}$ as well as $\mathrm{Au}$ particles on the catalyst surface. However, in the case of $\mathrm{Pt}$ and $\mathrm{Au}$, particles were incorporated on the $\mathrm{TiO}_{2}$ surface in an irregular manner presenting higher agglomeration of particles or the size of particles. XRD 
Table 1 Direct and indirect band gaps obtained using the Tauc plot (Fig. S3)

\begin{tabular}{llllll}
\hline Band gap & $\mathrm{TiO}_{2}(\mathrm{eV})$ & $\mathrm{TiO}_{2}-\mathrm{Ag}(\mathrm{eV})$ & $\mathrm{TiO}_{2}-\mathrm{Pt}(\mathrm{eV})$ & $\mathrm{TiO}_{2}-\mathrm{Au}(\mathrm{eV})$ & $\mathrm{TiO}_{2}-\mathrm{Pd}(\mathrm{eV})$ \\
\hline Direct & 3.38 & 3.22 & 3.23 & 3.19 & 3.13 \\
Indirect & 3.27 & 3.00 & 2.74 & 2.59 & 2.5 \\
\hline
\end{tabular}

measurement confirmed crystallographic forms after modification and showed that the anatase phase is predominant (Table S2). The results proved that surface modification with noble metals did not change significantly the basic structure of $\mathrm{TiO}_{2}$ (P25). Moreover, results indicated that titania, for the $\mathrm{TiO}_{2}-\mathrm{Au}$ nanoparticles, prepared by TIP, was present in the pure anatase structure. The size of anatase crystallites was the biggest for $\mathrm{TiO}_{2}-\mathrm{Pd}$ while the smallest for $\mathrm{TiO}_{2}-\mathrm{Au}$. The BET analysis shows that the specific surface area was not significantly changed after modification (Table S2).

As can be seen in Fig. 3a, the photocatalytic oxidation under UVA with $\mathrm{TiO}_{2}$ led to negligible paraben decontamination after $3 \mathrm{~h}$. Unfortunately, the photocatalytic oxidation with $\mathrm{TiO}_{2}$ modified by noble metals has not caused the complete degradation of paraben concentration; therefore, the COD reduction exceeded $20 \%$. In comparison to $\mathrm{TiO}_{2}$, only a slight improvement has been obtained when $\mathrm{TiO}_{2}-\mathrm{Au}$ was applied. The best results, but still not enough satisfactory, were obtained for $\mathrm{TiO}_{2}-\mathrm{Pd}$ and $\mathrm{TiO}_{2}-\mathrm{Ag}$ (Fig. 3a). The highest degradation was achieved for BeP (73\% and $53 \%$ of BeP initial concentration for $\mathrm{TiO}_{2}-\mathrm{Pd}$ and $\mathrm{TiO}_{2}-\mathrm{Ag}$, respectively). However, for the rest of parabens, the removal was below $50 \%$ of their concentration, while when COD removal is taken into account, only $19 \%$ and $17 \%$ were obtained after $3 \mathrm{~h}$ of the treatment for $\mathrm{TiO}_{2}-\mathrm{Pd}$ and $\mathrm{TiO}_{2}-\mathrm{Ag}$, respectively. It was surprising that despite the low initial paraben degradation during $\mathrm{TiO}_{2}-\mathrm{Pt}$ photocatalytic treatment, $18 \%$ of COD removal was achieved. In case of $\mathrm{TiO}_{2}$ as well as $\mathrm{TiO}_{2}-\mathrm{Au}$, the COD removal was around $10 \%$.

Much better results have been obtained when natural sunlight was applied. Indeed, significant improvement was observed for all catalysts. Moreover, the use of $\mathrm{TiO}_{2}-\mathrm{Pd}$ led to total paraben degradation (Fig. 3b). Also, higher degradation was achieved in the case of $\mathrm{TiO}_{2}-\mathrm{Pt}$ rather than for $\mathrm{TiO}_{2}-\mathrm{Ag}$, indicating that this photocatalyst has better visible light photocatalytic ability (Foszpańczyk et al. 2018). However, the highest improvement has been observed for $\mathrm{TiO}_{2}-\mathrm{Au}$, proving that the modification by Au increases the visible light ability, which is in agreement with absorption spectra. Despite higher degradation under sunlight, the effectivity of photocatalytic processes was much below expectation. Therefore, the catalytic ozonation as well as the photocatalytic ozonation have been investigated (Fig. 4). As it was expected, the catalytic ozonation as well as the photocatalytic ozonation increased effectivity. The parabens were totally removed during the first $2 \mathrm{~h}$ of both treatments, leading to higher mineralisation than for $\mathrm{O}_{3}$ or $\mathrm{O}_{3}$ /UVA. It is well known that the catalytic ozonation allows for the effective formation of hydroxyl radicals also at a low $\mathrm{pH}$ in contrast to single ozonation (Nawrocki and Kasprzyk-Hordern 2010). Furthermore, as expected, the photocatalytic ozonation led to higher COD removal. In case of $2 \mathrm{~h}$ of $\mathrm{O}_{3} / \mathrm{Cat}$ treatment, $\mathrm{TiO}_{2}$ and $\mathrm{TiO}_{2}$-Au exhibited similar effectivity (28\% of COD removal). While the application of $\mathrm{TiO}_{2}-\mathrm{Pt}, \mathrm{TiO}_{2}-\mathrm{Ag}$ and $\mathrm{TiO}_{2}-\mathrm{Pd}$ photocatalysts caused
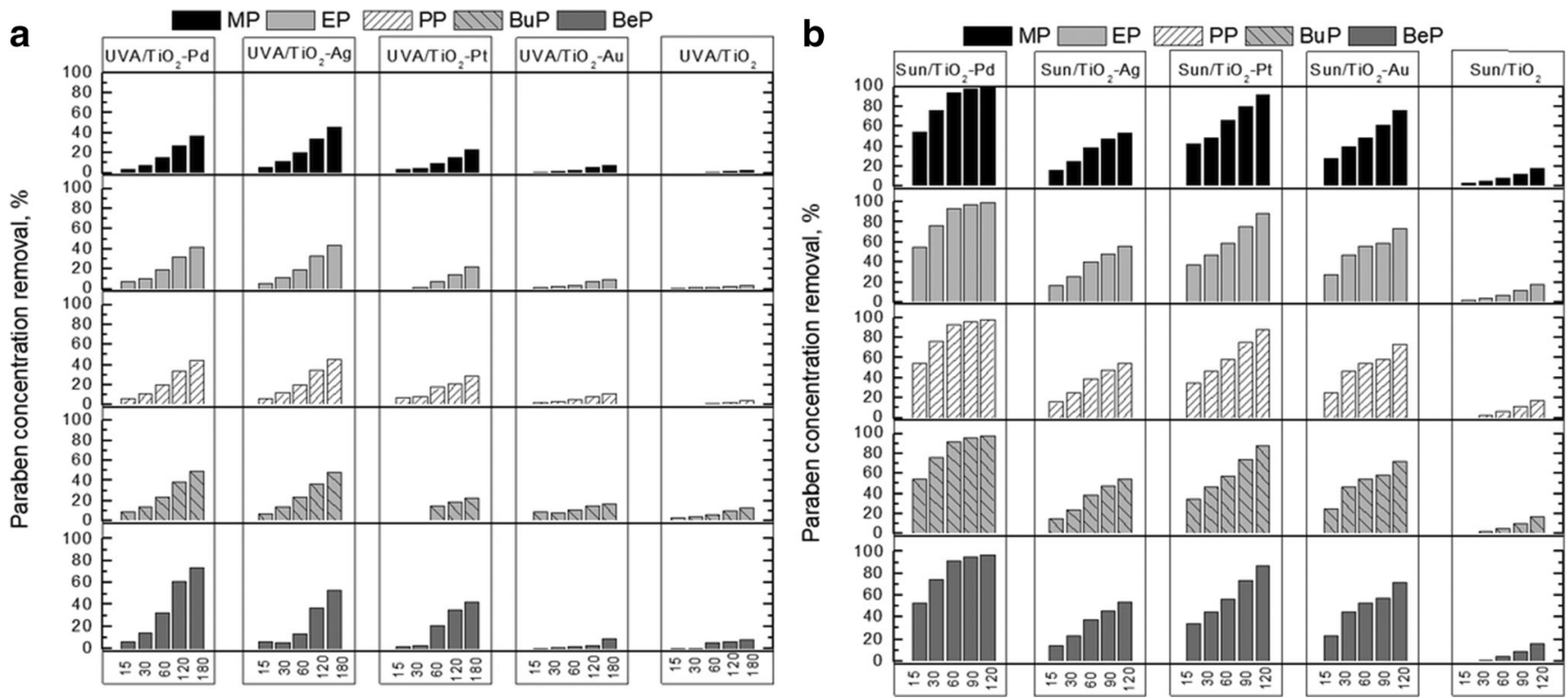

Fig. 3 Photocatalytic oxidation of paraben mixture under UVA (a) and natural sunlight (b) during $15 \mathrm{~min}, 30 \mathrm{~min}, 60 \mathrm{~min}, 120 \mathrm{~min}$ and $180 \mathrm{~min}$ 

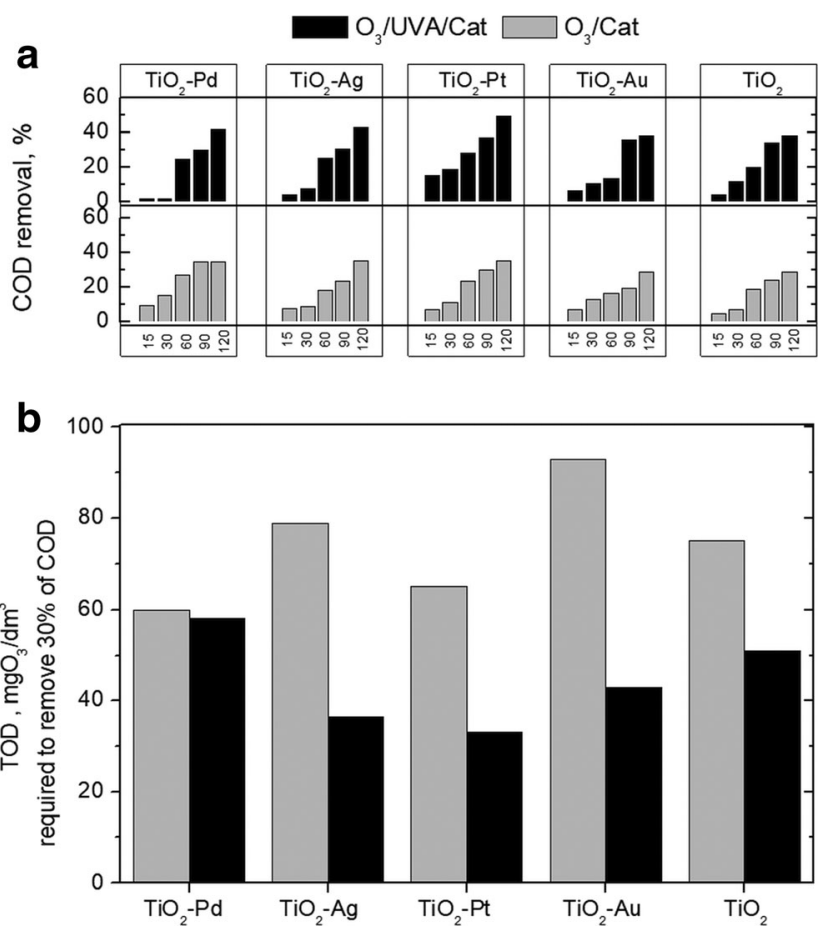

Fig. 4 a Catalytic and photocatalytic ozonation of paraben mixture during $15 \mathrm{~min}, 30 \mathrm{~min}, 60 \mathrm{~min}, 90 \mathrm{~min}$ and $120 \mathrm{~min}$. b TOD requirements for removing $30 \%$ of $\mathrm{COD}$ during catalytic and photocatalytic ozonation

around $35 \%$ of $\mathrm{COD}$ removal. After $2 \mathrm{~h}$ of $\mathrm{O}_{3} / \mathrm{UVA} / \mathrm{Cat}$ treatment, $38 \%$ of COD removal was achieved when $\mathrm{TiO}_{2}$ and $\mathrm{Au}-$ $\mathrm{TiO}_{2}$ were used, while $41 \%, 43 \%$ and $49 \%$ of COD were removed when $\mathrm{TiO}_{2}-\mathrm{Pd}, \mathrm{TiO}_{2}-\mathrm{Ag}$ and $\mathrm{TiO}_{2}-\mathrm{Pt}$, respectively, were applied. It was surprising that $\mathrm{O}_{3} / \mathrm{H}_{2} \mathrm{O}_{2}$ as well as $\mathrm{O}_{3}$ / $\mathrm{H}_{2} \mathrm{O}_{2}$ /UVA gave better COD removal (both above 33\%) efficiency than $\mathrm{O}_{3} / \mathrm{Cat}$ and $\mathrm{O}_{3} / \mathrm{UVA} / \mathrm{Cat}$ after $1 \mathrm{~h}, 27 \%\left(\mathrm{TiO}_{2}\right.$ $\mathrm{Pd})$ and $28 \%\left(\mathrm{TiO}_{2}-\mathrm{Pt}\right)$, respectively] (Figs. 2 and 4$)$. However, when TOD is taken into account, the requirements are much lower when catalytic ozonation and photocatalytic ozonation were considered (Fig. S3, Fig. 4b). As can be seen in Fig. 4b, the orders of the highest ozone-demanding catalysts are $\mathrm{TiO}_{2}-\mathrm{Au}<\mathrm{TiO}_{2}-\mathrm{Ag}<\mathrm{TiO}_{2}<\mathrm{TiO}_{2}-\mathrm{Pt}<\mathrm{TiO}_{2}-\mathrm{Pd}$ and $\mathrm{TiO}_{2}-\mathrm{Pd}<\mathrm{TiO}_{2}<\mathrm{TiO}_{2}-\mathrm{Au}<\mathrm{TiO}_{2}-\mathrm{Ag}<\mathrm{TiO}_{2}$-Pt during $\mathrm{O}_{3} /$ Cat and $\mathrm{O}_{3} / \mathrm{UVA} / \mathrm{Cat}$, respectively. The differences can be related with ozone adsorption on the surface of the catalyst and whether this process leads to ozone decomposition followed by the formation of surface-bound or free radicals (Nawrocki and Kasprzyk-Hordern 2010) and with absorption of light ability. In fact, the presence of UVA with these catalysts photogenerates electrons that can be trapped by ozone reducing to ozonide radical which, in acidic conditions, can be adjuvant on hydroxyl radical production (Mehrjouei et al. 2015; Gomes et al. 2017d, 2018b).

\section{Kinetic studies}

Kinetic studies for applied AOPs were performed for the degradation of each paraben in admixture assuming pseudo-firstorder kinetics. The pseudo-first-order kinetic model fitted well with the experimental results with coefficients of determination $\left(R^{2}\right)$ ranging from 0.790 to 0.998 . Pseudo-first-order rate constants $\left(k^{\prime}\right)$ of the processes are collected in Tables 2, 3 and 4.

Firstly, the ozone and hydrogen peroxide process will be discussed (Table 2). The calculated values of pseudo-firstorder rate constants for the $\mathrm{H}_{2} \mathrm{O}_{2} / \mathrm{UVC}$ process for all parabens are 1 order of magnitude higher than those for other processes. It must be mentioned that for this process, the complete removal of each paraben was achieved after just $30 \mathrm{~min}$., while for the $\mathrm{H}_{2} \mathrm{O}_{2} / \mathrm{O}_{3} / \mathrm{UVA}$ process, 90 min was required. The rest of the processes $\left(\mathrm{O}_{3}, \mathrm{H}_{2} \mathrm{O}_{2} / \mathrm{UVC}, \mathrm{H}_{2} \mathrm{O}_{2} / \mathrm{O}_{3}\right.$, UVA/ $\mathrm{O}_{3}$ ) needed $2 \mathrm{~h}$ or $3 \mathrm{~h}$ to remove the paraben concentration at the satisfactory levels. Despite maintaining the same order of magnitude of $k^{\prime}$, the slight increase in the following order (average values between brackets): $\mathrm{O}_{3}(0.02475 \pm 0.0102$ $1 / \mathrm{min}), \mathrm{H}_{2} \mathrm{O}_{2} / \mathrm{O}_{3}(0.02839 \pm 0.0026 \mathrm{~L} / \mathrm{min}), \mathrm{UVA} / \mathrm{O}_{3}$

Table 2 Pseudo-first-order rate constants for paraben mixture phototransformation during $\mathrm{O}_{3}, \mathrm{H}_{2} \mathrm{O}_{2} / \mathrm{UVC}, \mathrm{H}_{2} \mathrm{O}_{2} / \mathrm{O}_{3}, \mathrm{UVA} / \mathrm{O}_{3}$ and $\mathrm{H}_{2} \mathrm{O}_{2} / \mathrm{O}_{3} /$ UVA processes

\begin{tabular}{|c|c|c|}
\hline Process & Paraben & $k^{\prime}(1 / \mathrm{min})$ \\
\hline \multirow[t]{5}{*}{$\mathrm{O}_{3}(8 \mathrm{mg} \mathrm{O} / \mathrm{L})$} & MP & 0.01737 \\
\hline & $\mathrm{EP}$ & 0.02295 \\
\hline & PP & 0.0245 \\
\hline & $\mathrm{BuP}$ & 0.01699 \\
\hline & $\mathrm{BeP}$ & 0.04192 \\
\hline \multirow[t]{5}{*}{$\mathrm{H}_{2} \mathrm{O}_{2} / \mathrm{UVC}$} & MP & 0.62102 \\
\hline & $\mathrm{EP}$ & 0.75672 \\
\hline & $\mathrm{PP}$ & 0.65232 \\
\hline & $\mathrm{BuP}$ & 0.56989 \\
\hline & $\mathrm{BeP}$ & 0.88343 \\
\hline \multirow[t]{5}{*}{$\mathrm{H}_{2} \mathrm{O}_{2} / \mathrm{O}_{3}\left(70 \mathrm{mg} \mathrm{H}_{2} \mathrm{O}_{2} / \mathrm{L}, 8 \mathrm{mg} \mathrm{O}_{3} / \mathrm{L}\right)$} & MP & 0.02847 \\
\hline & $\mathrm{EP}$ & 0.02483 \\
\hline & PP & 0.02701 \\
\hline & $\mathrm{BuP}$ & 0.03038 \\
\hline & $\mathrm{BeP}$ & 0.03128 \\
\hline \multirow[t]{5}{*}{$\mathrm{UVA} / \mathrm{O}_{3}(8 \mathrm{mg} \mathrm{O} / \mathrm{L})$} & MP & 0.03111 \\
\hline & $\mathrm{EP}$ & 0.02938 \\
\hline & $\mathrm{PP}$ & 0.03151 \\
\hline & $\mathrm{BuP}$ & 0.02776 \\
\hline & $\mathrm{BeP}$ & 0.03264 \\
\hline \multirow[t]{5}{*}{$\mathrm{H}_{2} \mathrm{O}_{2} / \mathrm{O}_{3} /$ UVA (13.5 $\left.\mathrm{mg} \mathrm{H}_{2} \mathrm{O}_{2} / \mathrm{L}\right)$} & MP & 0.036 \\
\hline & EP & 0.0363 \\
\hline & $\mathrm{PP}$ & 0.04206 \\
\hline & $\mathrm{BuP}$ & 0.03402 \\
\hline & $\mathrm{BeP}$ & 0.03585 \\
\hline
\end{tabular}


Table 3 Pseudo-first-order rate constants for paraben mixture phototransformation during the photocatalytic oxidation under UVA and natural sunlight irradiation

\begin{tabular}{|c|c|c|c|}
\hline Process & Paraben & Type of catalyst & $k^{\prime}(1 / \mathrm{min})$ \\
\hline UVA/Cat & $\mathrm{BuP}$ & 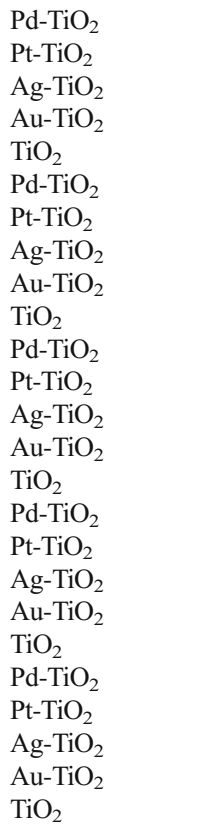 & $\begin{array}{l}0.00275 \\
0.00135 \\
0.00347 \\
0.00047 \\
0.00011 \\
0.00295 \\
0.00148 \\
0.0033 \\
0.00053 \\
0.000229 \\
0.00336 \\
0.00167 \\
0.00353 \\
0.00057 \\
0.000226 \\
0.00377 \\
0.0015 \\
0.00371 \\
0.00077 \\
0.000813 \\
0.00751 \\
0.00345 \\
0.00414 \\
0.00071 \\
0.000544\end{array}$ \\
\hline Sun/Cat & $\mathrm{BuP}$ & 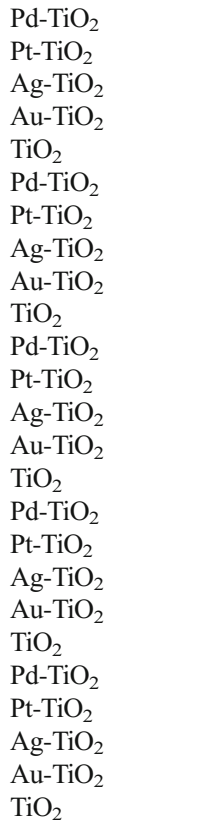 & $\begin{array}{l}0.0404 \\
0.01955 \\
0.00699 \\
0.01149 \\
0.00158 \\
0.03975 \\
0.01736 \\
0.00731 \\
0.01155 \\
0.00149 \\
0.03653 \\
0.01692 \\
0.00715 \\
0.01132 \\
0.0014 \\
0.03452 \\
0.01658 \\
0.00702 \\
0.01113 \\
0.00132 \\
0.03241 \\
0.01597 \\
0.00685 \\
0.01079 \\
0.00119\end{array}$ \\
\hline
\end{tabular}

$(0.03048 \pm 0.0019 \mathrm{~L} / \mathrm{min})$ and $\mathrm{H}_{2} \mathrm{O}_{2} / \mathrm{O}_{3} / \mathrm{UVA}(0.03685 \pm$ $0.0031 \mathrm{~L} / \mathrm{min}$ ) can be observed. As can be concluded from the $k^{\prime}$ values, the synergetic effect can be seen when the $\mathrm{H}_{2} \mathrm{O}_{2} /$ $\mathrm{O}_{3} /$ UVA process was used, but considering COD removal (Fig. 2), the benefits are not predominant in comparison to the $\mathrm{H}_{2} \mathrm{O}_{2} / \mathrm{O}_{3}$ process.
When the photocatalytic oxidation process is considered (Table 3), it can be seen that the calculated values of pseudofirst-order rate constants for the processes under sunlight irradiation are 1 order of magnitude higher than those for the process under UVA conditions. The exceptions are $\mathrm{TiO}_{2}-\mathrm{Ag}$ and $\mathrm{TiO}_{2}-\mathrm{Au}$. For $\mathrm{TiO}_{2}-\mathrm{Ag}$, the $k^{\prime}$ is, on average, twice as high using the natural sun in comparison with UVA $(0.00706 \pm$ $0.00017 \mathrm{~L} / \mathrm{min}$ and $0.00363 \pm 0.00032 \mathrm{~L} / \mathrm{min}$ (average values), respectively), while for $\mathrm{TiO}_{2}-\mathrm{Au}$, the $k^{\prime}$ determined for photocatalytic oxidation under sunlight condition is 2 orders of magnitude higher $(0.01126 \pm 0.0003 \mathrm{~L} / \mathrm{min})$ than that in UVA condition $(0.00061 \pm 0.00016 \mathrm{~L} / \mathrm{min})$. However, the highest $k^{\prime}$ values were obtained for $\mathrm{Pd}^{-\mathrm{TiO}_{2}}(0.00407 \pm$ $0.00196 \mathrm{~L} / \mathrm{min}$ and $0.03672 \pm 0.0034 \mathrm{~L} / \mathrm{min}$ (average values), respectively), UVA/Cat and Sun/Cat processes.

However, when the catalytic ozonation is compared with photocatalytic ozonation, the pseudo-first-order kinetic constants are similar with a slight advantage in favour of the $\mathrm{UVA} / \mathrm{Cat} / \mathrm{O}_{3}$. But when COD removal is taken into account, the implementation of UVA is not reasonable.

In case of all processes, the pseudo-first-order kinetic constants for methylparaben were the lowest while the highest values were obtained for benzylparaben degradation.

\section{Proposed mechanism}

It is known that generally AOPs enable a high degree of degradation of hazardous aqueous contaminants in a short time. Its wide application is connected with $\bullet \mathrm{OH}$ generation in near ambient condition (temperature and pressure). The $\bullet \mathrm{OH}$ is one of the most powerful oxidants and the most commonly used in water treatment processes, due to its non-selectivity (Glaze et al. 1987). As presented above, many processes are qualified as AOP. The well known are processes involving combinations of $\mathrm{O}_{3}, \mathrm{H}_{2} \mathrm{O}_{2}$, $\mathrm{UV}, \mathrm{TiO}_{2}$ and Fenton reagent. The mechanism of those processes is widely investigated. In the $\mathrm{H}_{2} \mathrm{O}_{2} / \mathrm{UVC}$ system, the cleavage of $\mathrm{H}_{2} \mathrm{O}_{2}$ with UVC light produces a quantum yield of two ${ }^{\circ} \mathrm{OH}$ radicals per unit of radiation absorbed (Eq. (1)). However, the $\varepsilon_{254}$ value of $\mathrm{H}_{2} \mathrm{O}_{2}$ is very low $\left(19.6 \mathrm{M}^{-1} / \mathrm{cm}\right)$ (Glaze et al. 1987), which determines its very high concentration to produce sufficient ${ }^{\circ} \mathrm{OH}$. Moreover, as can be seen in Fig. $1 \mathrm{~b}, \mathrm{H}_{2} \mathrm{O}_{2}$ is able to absorb photons below $300 \mathrm{~nm}$, which excludes the UVA lamps.

$\mathrm{H}_{2} \mathrm{O}_{2}+h v \leftrightarrow 2^{\circ} \mathrm{OH}$

The Fenton process overcomes these drawbacks because the oxidation processes utilise the activation of $\mathrm{H}_{2} \mathrm{O}_{2}$ by iron salts which allows the generation of ${ }^{\circ} \mathrm{OH}$ (Eq. (2)). Moreover, $\mathrm{Fe}^{3+}$ can react with $\mathrm{H}_{2} \mathrm{O}_{2}$ and hydroperoxyl radical (so-called 'Fenton-like reaction'), which leads to $\mathrm{Fe}^{2+}$ regeneration (Eq. (3))

$\mathrm{Fe}^{2+}+\mathrm{H}_{2} \mathrm{O}_{2} \rightarrow \mathrm{HO}^{-}+{ }^{\circ} \mathrm{OH}+\mathrm{Fe}^{3+}$ 
Table 4 Pseudo-first-order rate constants for paraben mixture phototransformation during the photocatalytic oxidation under UVA and natural sunlight irradiation

\begin{tabular}{|c|c|c|c|}
\hline Process & Paraben & Type of catalyst & $k^{\prime}(1 / \mathrm{min})$ \\
\hline \multirow{25}{*}{$\mathrm{O}_{3} /$ Cat } & \multirow[t]{5}{*}{ MP } & $\mathrm{Pd}-\mathrm{TiO}_{2}$ & 0.03345 \\
\hline & & Pt-TiO 2 & 0.03507 \\
\hline & & $\mathrm{Ag}-\mathrm{TiO}_{2}$ & 0.0204 \\
\hline & & $\mathrm{Au}-\mathrm{TiO}_{2}$ & 0.01832 \\
\hline & & $\mathrm{TiO}_{2}$ & 0.02372 \\
\hline & \multirow[t]{5}{*}{ EP } & $\mathrm{Pd}-\mathrm{TiO}_{2}$ & 0.03071 \\
\hline & & Pt-TiO ${ }_{2}$ & 0.03395 \\
\hline & & $\mathrm{Ag}-\mathrm{TiO}_{2}$ & 0.0187 \\
\hline & & $\mathrm{Au}-\mathrm{TiO}_{2}$ & 0.01641 \\
\hline & & $\mathrm{TiO}_{2}$ & 0.02136 \\
\hline & \multirow[t]{5}{*}{ PP } & $\mathrm{Pd}-\mathrm{TiO}_{2}$ & 0.03267 \\
\hline & & Pt-TiO 2 & 0.03409 \\
\hline & & $\mathrm{Ag}-\mathrm{TiO}_{2}$ & 0.02043 \\
\hline & & $\mathrm{Au}-\mathrm{TiO}_{2}$ & 0.01801 \\
\hline & & $\mathrm{TiO}_{2}$ & 0.02342 \\
\hline & \multirow[t]{5}{*}{$\mathrm{BuP}$} & $\mathrm{Pd}-\mathrm{TiO}_{2}$ & 0.02383 \\
\hline & & Pt-TiO 2 & 0.02019 \\
\hline & & $\mathrm{Ag}-\mathrm{TiO}_{2}$ & 0.01782 \\
\hline & & $\mathrm{Au}-\mathrm{TiO}_{2}$ & 0.01811 \\
\hline & & $\mathrm{TiO}_{2}$ & 0.02343 \\
\hline & \multirow[t]{5}{*}{$\mathrm{BeP}$} & $\mathrm{Pd}-\mathrm{TiO}_{2}$ & 0.05988 \\
\hline & & Pt-TiO & 0.03812 \\
\hline & & $\mathrm{Ag}-\mathrm{TiO}_{2}$ & 0.03639 \\
\hline & & $\mathrm{Au}-\mathrm{TiO}_{2}$ & 0.03453 \\
\hline & & $\mathrm{TiO}_{2}$ & 0.04889 \\
\hline \multirow[t]{25}{*}{$\mathrm{UVA} / \mathrm{Cat} / \mathrm{O}_{3}$} & \multirow[t]{5}{*}{ MP } & $\mathrm{Pd}-\mathrm{TiO}_{2}$ & 0.04346 \\
\hline & & $\mathrm{Pt}-\mathrm{TiO}_{2}$ & 0.03698 \\
\hline & & $\mathrm{Ag}-\mathrm{TiO}_{2}$ & 0.03925 \\
\hline & & $\mathrm{Au}-\mathrm{TiO}_{2}$ & 0.02933 \\
\hline & & $\mathrm{TiO}_{2}$ & 0.03886 \\
\hline & \multirow[t]{5}{*}{ EP } & $\mathrm{Pd}-\mathrm{TiO}_{2}$ & 0.04258 \\
\hline & & Pt-TiO 2 & 0.03443 \\
\hline & & $\mathrm{Ag}-\mathrm{TiO}_{2}$ & 0.03946 \\
\hline & & $\mathrm{Au}-\mathrm{TiO}_{2}$ & 0.02716 \\
\hline & & $\mathrm{TiO}_{2}$ & 0.03816 \\
\hline & \multirow[t]{5}{*}{ PP } & $\mathrm{Pd}-\mathrm{TiO}_{2}$ & 0.04542 \\
\hline & & $\mathrm{Pt}-\mathrm{TiO}_{2}$ & 0.03725 \\
\hline & & $\mathrm{Ag}-\mathrm{TiO}_{2}$ & 0.04022 \\
\hline & & $\mathrm{Au}-\mathrm{TiO}_{2}$ & 0.02918 \\
\hline & & $\mathrm{TiO}_{2}$ & 0.03506 \\
\hline & \multirow[t]{5}{*}{$\mathrm{BuP}$} & $\mathrm{Pd}-\mathrm{TiO}_{2}$ & 0.03978 \\
\hline & & Pt-TiO 2 & 0.03912 \\
\hline & & $\mathrm{Ag}-\mathrm{TiO}_{2}$ & 0.03673 \\
\hline & & $\mathrm{Au}-\mathrm{TiO}_{2}$ & 0.02427 \\
\hline & & $\mathrm{TiO}_{2}$ & 0.02993 \\
\hline & \multirow[t]{5}{*}{$\mathrm{BeP}$} & $\mathrm{Pd}-\mathrm{TiO}_{2}$ & 0.05755 \\
\hline & & Pt-TiO & 0.03777 \\
\hline & & $\mathrm{Ag}-\mathrm{TiO}_{2}$ & 0.05482 \\
\hline & & $\mathrm{Au}-\mathrm{TiO}_{2}$ & 0.03312 \\
\hline & & $\mathrm{TiO}_{2}$ & 0.04214 \\
\hline
\end{tabular}

$\mathrm{Fe}^{3+}+\mathrm{H}_{2} \mathrm{O}_{2} \rightarrow \mathrm{HO}_{2} \cdot+\mathrm{H}^{+}+\mathrm{Fe}^{2+}$

The reaction based on $\mathrm{O}_{3}$ is more complicated. Firstly, the mechanism of its action is strongly dependent on $\mathrm{pH}$ (as discussed above): at high $\mathrm{pH}$ values, ozone acts not just by direct reaction but also by formation and reaction of ${ }^{\circ} \mathrm{OH}$. The decomposition of ozone in a cyclic chain process can be indicated by hydroxide ion (Fig. 5a), $\mathrm{H}_{2} \mathrm{O}_{2}$ supplementation to the system or photolysis of ozone (Fig. 5b). Moreover, despite the two pathways, both the formations of hydrogen peroxide can occur, which can initiate chain decomposition of ozone, resulting in 'OH formation (Glaze 1986). Therefore, even reactions that are performed below or near neutral $\mathrm{pH}$ may have a component of radical character, because peroxide is often a by-product of the ozonolysis (Glaze 1986). Moreover, the stoichiometric yield of • $\mathrm{OH}$ is greater from the photolysis of $\mathrm{H}_{2} \mathrm{O}_{2}$ (only $0.5 \mathrm{~mol} \mathrm{H}_{2} \mathrm{O}_{2}$ is consumed for $1 \mathrm{~mol}$ of ${ }^{\circ} \mathrm{OH}$ production) in comparison to the photolysis of ozone $\left(1.5 \mathrm{~mol} \mathrm{O}_{3}\right.$ is consumed for $1 \mathrm{~mol}$ of $\bullet \mathrm{OH}$ production (and at the same time, $0.5 \mathrm{~mol} \mathrm{H}_{2} \mathrm{O}_{2}$ is formed in situ)) at the same UVC fluence dose (Glaze et al. 1987). When $\mathrm{O}_{3} / \mathrm{H}_{2} \mathrm{O}_{2}$ is considered, only $1 \mathrm{~mol} \mathrm{O}_{3}$ and $0.5 \mathrm{~mol} \mathrm{H}_{2} \mathrm{O}_{2}$ are required to form $1 \mathrm{~mol}^{\circ} \mathrm{OH}$ (Glaze et al. 1987). However, taking into account the absorption coefficients, the higher amount of 'OH is formed during $\mathrm{O}_{3}$ photolysis ( 2 radicals per incident photon) than $\mathrm{H}_{2} \mathrm{O}_{2}$ photolysis ( 0.09 radicals per incident photon). Therefore, $\mathrm{O}_{3} / \mathrm{H}_{2} \mathrm{O}_{2}$ and $\mathrm{O}_{3} / \mathrm{H}_{2} \mathrm{O}_{2} / \mathrm{UV}$ have higher effectivity and are more cost-effective (Lucas et al. 2010).

It is known that in the $\mathrm{TiO}_{2}$ photocatalytic process, the photocatalytic activity is exhibited by photogenerated charge carriers which is a consequence of the $\mathrm{TiO}_{2}$ activation by radiation with energy higher than its band gap energy. Positive holes $\left(h^{+}\right)$are responsible for oxidising organic compounds due to reactions with a water molecule or $\mathrm{OH}$ ions and ${ }^{\circ} \mathrm{OH}$ radicals (Gmurek et al. 2017), while negative electrons $(e)$ for reducing molecular oxygen to superoxide radical anions (Fig. 5c). Moreover, the generation of $\mathrm{H}_{2} \mathrm{O}_{2}$ from the electroreduction of oxygen occurred that may also lead to the production of $\bullet \mathrm{OH}$ radicals (Salvador 2007; Xiao et al. 2015), while modification of $\mathrm{TiO}_{2}$ by a noble metal changed the mechanism of electron transfer. The photons are absorbed by semiconductor $\left(\mathrm{TiO}_{2}\right)$ and/or also by metal nanoparticles through their LSPR excitation (mostly in case of Ag and $\mathrm{Au}$ ) (Bumajdad and Madkour 2014; Zielińska-Jurek 2014; Wysocka et al. 2018); see Fig. 5d-f. The enhancement in photoactivity is attributed to Schottky barriers under UV range radiation and to LSPR that induces a collective coherent oscillation of the conducting band electrons of the metal nanoparticles. However, it should be mentioned that under UV irradiation (where energy is much higher than the surface plasmon resonance (SPR), the improvement in photoactivity is not related to SPR (Bumajdad and Madkour 2014). However, under visible range, the enhancement is strongly related with LSPR and Schottky barrier (Wysocka et al. 2018; Borowska et al. 2019). Moreover, the electron transfer through the noble metal/ $/ \mathrm{TiO}_{2}$ interface under a wide range (UVA and visible) occurred (Hu and Bürgi 2012). The differences between ozone-based or hydrogen peroxide-based AOP and photocatalysis with semiconductors modified by noble metals indicate that photodegradation can be attributed not only to ${ }^{\circ} \mathrm{OH}$ radicals but also to other forms of reactive oxygen species (ROS) $\mathrm{O}_{2}^{-}{ }^{-},{ }^{1} \mathrm{O}_{2}$ and $\mathrm{H}_{2} \mathrm{O}_{2}$ or $e_{\mathrm{cb}}{ }^{-}$and $h^{+}$(Wysocka et al. 2018).

The addition of ozone significantly enhances the mineralisation prior to heterogeneous photocatalysis alone or 
Fig. 5 Schematic illustration of the proposed reaction mechanism for ozone-based processes $(\mathbf{a}, \mathbf{b})$, photocatalytic oxidation for $\mathrm{TiO}_{2}$ (c) and noble metals (d-f) as well as photocatalytic ozonation (g) [based on Glaze 1986, Glaze et al. 1987, Bumajdad and Madkour 2014, Zielińska-Jurek 2014 and Xiao et al. 2015]
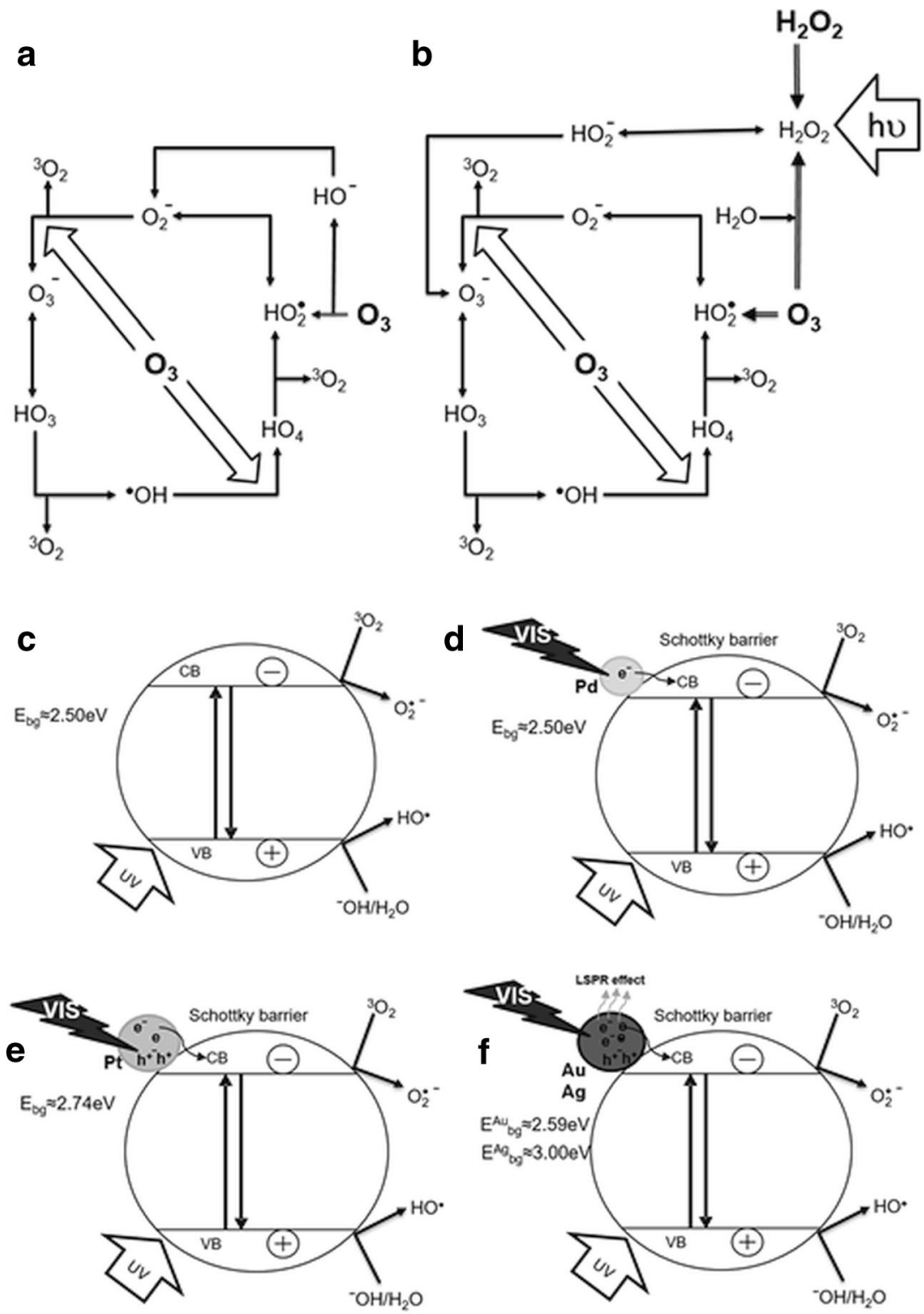

g

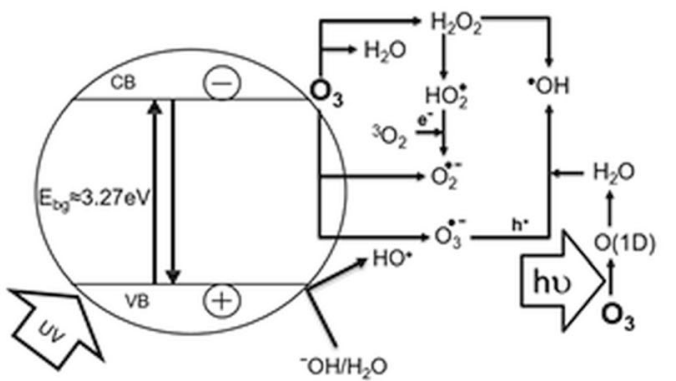

even in case of catalysis. This synergetic effect is due to ready hydroxylation of the semiconductor catalyst in aqueous solution (Xiao et al. 2015). Heterogeneous photocatalytic ozonation is a very complicated system that involves chemical, catalytic and photocatalytic reactions. The improvement of the mineralisation during simultaneously occurring photocatalysis and ozonation synergistically intensified the formation of free radicals (Fig. $5 \mathrm{~g}$ ).

Based on the experiments of scavengers, the main degradation pathways via ${ }^{\circ} \mathrm{OH}$ were proved for $\mathrm{H}_{2} \mathrm{O}_{2} / \mathrm{Fe}^{2+}, \mathrm{H}_{2} \mathrm{O}_{2} / \mathrm{UVC}, \mathrm{O}_{3} /$ $\mathrm{H}_{2} \mathrm{O}_{2}, \mathrm{O}_{3} /$ UVA, $\mathrm{O}_{3} / \mathrm{H}_{2} \mathrm{O}_{2} /$ UVA, UVA/Cat, $\mathrm{O}_{3} /$ Cat and $\mathrm{O}_{3} / \mathrm{UVA} /$ Cat. It is known that oxidation of aqueous water contaminants can be proceeded via direct oxidation (the reaction of free holes/ 
electrons with adsorbed contaminates) or indirect oxidation (through oxidation by ROS). However, in photocatalytic processes in which the hydroxyl radicals were confirmed as the main oxidants, the other ROS present in the system (such as ozone, ozonide and superoxide radicals) have a lower effect on paraben degradation and by-product formation and further decay. As a main transformation by-product, $p$-hydroxybenzoic acid, 2,4dihydroxybenzoic acid and 3,4-dihydroxybenzoic acid as well as monohydroxylated parabens were identified and confirmed the degradation pathway during AOP treatment accoutred predominantly via hydroxylation (Fig. S6).

\section{Mineralisation, biodegradability and toxicity assessment}

For the tested AOPs, the degree of mineralisation was assessed. As discussed above, the mineralisation was expressed by COD. However, for a deeper analysis, total organic carbon (TOC) removal (after $2 \mathrm{~h}$ ) will be discussed as well (Table S3). Between $80 \%$ and $90 \%$ COD reduction and $50 \%$ TOC removal were observed after 60 min of treatment. As discussed above, the highest COD removal was obtained when $\mathrm{H}_{2} \mathrm{O}_{2} / \mathrm{UVC}$ was used, which also corresponded with the highest TOC removal. Very good COD reduction was observed after $\mathrm{O}_{3} / \mathrm{H}_{2} \mathrm{O}_{2}(70 \%)$, while TOC removal was equal to $26 \%$. For all catalytic processes, the highest TOC reduction was achieved when $\mathrm{TiO}_{2}$-Pd was used: UVA/Cat (25\%), Sun/
Cat (34\%), $\mathrm{O}_{3} / \mathrm{Cat}(18 \%)$ and $\mathrm{UVA} / \mathrm{O}_{3} / \mathrm{Cat}(38 \%)$. In case of UVA/Cat, Sun/Cat and $\mathrm{O}_{3} / \mathrm{Cat}$, there were no significant differences between the other photocatalysts. The application of $\mathrm{UVA} / \mathrm{O}_{3} / \mathrm{Cat}$ process caused the highest $\mathrm{COD}$ as well as TOC removal (Table S3). The TOC and COD analysis showed that the total mineralisation was not achieved in any of the processes. It can be suspected that organic transformation byproducts are still present in solution after treatments. Therefore, it is necessary to investigate the biodegradability as well as the toxicity of the solution after the treatment. The biodegradability study was based on the investigation of changes in the degree of oxidation, which is an indicator of the oxidation degree of complex solutions, providing indirect information on their probability of biodegradation. The COD/ TOC values and average oxidation state (AOS) were used for biodegradability evaluation (Al Momani et al. 2004). The results are shown in Fig. 6.

The initial solution containing a mixture of parabens was characterised by $\mathrm{COD} / \mathrm{TOC}$ factor equal to 2.91. It should be mentioned that lower COD/TOC ratios imply a higher degree of oxidation while higher ratios mean lower oxidation. As can be seen in Fig. 6, the much higher value of that parameter was obtained after single ozonation, which confirmed that a lot of complexed transformation by-products were present after this treatment. In case of catalytic processes, it seems that when just photocatalytic oxidation or photocatalytic ozonation occurred, the complexity of
Fig. 6 Biodegradability assessment of COD/TOC and AOS $B$ values obtained for the decomposition of paraben mixture after several AOPs
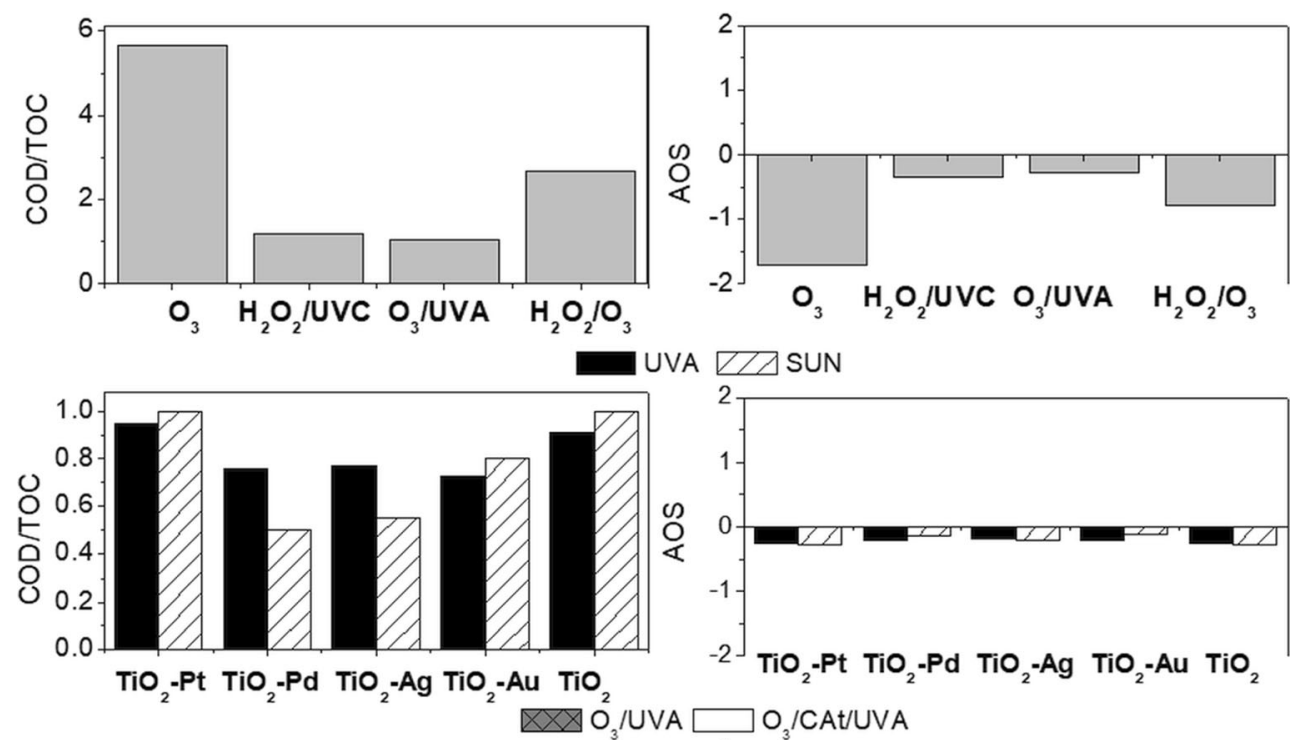

UVA $R Z$ SUN
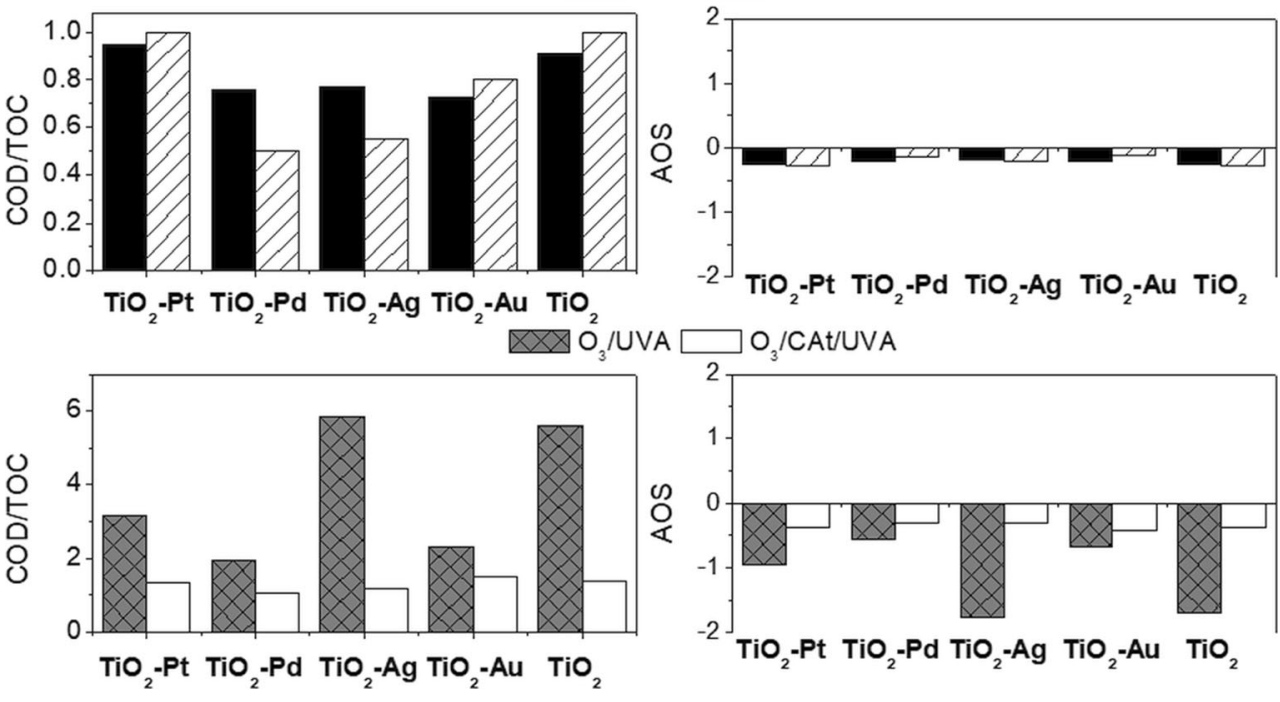
transformation by-products decreased, despite high differences between COD and TOC removal, while when the catalytic ozonation was proceeded, the $\mathrm{COD} / \mathrm{TOC}$ is higher than that for initial solution. Moreover, for $\mathrm{TiO}_{2}$ and $\mathrm{TiO}_{2}-$ $\mathrm{Ag}$, the values of that parameter were similar to single ozonation.

It is known that AOS is a valuable parameter that can be used as a general oxidation measure of complex mixtures containing various oxidation products. Theoretically, AOS can take values between +4 for $\mathrm{CO}_{2}$ (the most oxidised state of $\mathrm{C}$ ) and -4 for $\mathrm{CH}_{4}$ (the most reduced state of $\mathrm{C}$ ). For example, the AOS for benzene is -1 , that for formaldehyde and acetic acids is 0 while that for formic acid and oxalic acid is +2 and +3 , respectively (Al Momani et al. 2004). As can be seen in Fig. 6, almost all of the tested AOPs resulted in significant increases in the AOS values (initial AOS $=-2.27$ ). The AOS values after $\mathrm{H}_{2} \mathrm{O}_{2} / \mathrm{UV}, \mathrm{O}_{3} / \mathrm{UVA}$, photocatalytic oxidation (both UVA and Sun) and photocatalytic ozonation confirmed that more oxidised by-products are obtained. However, it is still not as simple as carboxylic acids. The lowest oxidation degree was achieved in the case of single ozonation or catalytic oxidation when $\mathrm{TiO}_{2}$ and $\mathrm{TiO}_{2}$-Ag were used, confirming results from $\mathrm{COD} / \mathrm{TOC}$ parameter.

As can be seen in Table 5 and as discussed above, almost all processes led to complete degradation of paraben concentration after $120 \mathrm{~min}$. Moreover, when some processes have been applied, the removal of each paraben was achieved much faster. Only during photocatalytic oxidation the degradation after $3 \mathrm{~h}$ was incredibly low, and the decontamination has been influenced by the photocatalysts. For all effluents (containing paraben mixture) before treatment, the initial COD value as well as Aliivibrio fischeri luminescence inhibition (LI) after $15 \mathrm{~min}$ of exposure were $102 \pm 7.5 \mathrm{mg} \mathrm{O}_{2} / \mathrm{L}$ and $95.57 \pm 0.04 \%$, respectively.

The best results of COD removal have been obtained when $\mathrm{H}_{2} \mathrm{O}_{2} / \mathrm{UVC}$ and $\mathrm{H}_{2} \mathrm{O}_{2} / \mathrm{Fe}^{2+}$ were applied, in spite of the lowest time of treatment $(1 \mathrm{~h})$. Contrarily, the worst COD abatement was obtained by photocatalytic oxidation (UVA) when the treatment time was the longest one $(3 \mathrm{~h})$. It should be noticed that during this process, no more than $50 \%$ removal of each paraben concentration was achieved, while during the other processes, the degradation of parabens was obtained before $120 \mathrm{~min}$.

The initial paraben mixture was highly toxic to A. fischeri. During the reaction, the toxicity has been reduced. According to the literature, the sample can be considered non-toxic when LI is below 30\% (Miralles-Cuevas et al. 2017). Taking this value into account, for the Fenton process and $\mathrm{H}_{2} \mathrm{O}_{2} / \mathrm{UVC}$, non-toxic effluents have been achieved. Similar effect has been obtained for $\mathrm{O}_{3} / \mathrm{H}_{2} \mathrm{O}_{2}$ and $\mathrm{O}_{3} / \mathrm{UVA}$ (irrespective to COD removal). When the processes with photocatalysts were considered, large differences have been noticed. It was found
Table 5 Maximum paraben concentration, COD removal, A. fischeri luminescence inhibition (15 min of exposure $\left.\left(\mathrm{LI}^{15 \mathrm{~min}}\right)\right)$, C. fluminea mortality and $L$. sativum germination index (GI) after 120 min of treatment

\begin{tabular}{|c|c|c|c|c|c|}
\hline Process & Max. $C^{\text {parabens }}$ & $\operatorname{COD}(\%)$ & $\mathrm{LI}^{15 \mathrm{~min}}$ & Mortality & GI $(\%)$ \\
\hline $\mathrm{H}_{2} \mathrm{O}_{2} / \mathrm{Fe}^{2+*}$ & $100 \%$ & 40 & $\mathrm{Nd}^{\#}$ & $37 \%$ & \\
\hline $\mathrm{H}_{2} \mathrm{O}_{2} / \mathrm{UVC}^{*}$ & $100 \%$ & 41 & $\mathrm{Nd}^{\#}$ & & \\
\hline $\mathrm{UVA} / \mathrm{TiO}_{2}{ }^{¥}$ & $12 \%^{\mathrm{BuP}}$ & 10 & $>80 \%$ & $a b / p$ & $(43 \pm 0)$ \\
\hline $\mathrm{UVA} / \mathrm{TiO}_{2}-\mathrm{Pt}^{¥}$ & $42 \%^{\mathrm{BeP}}$ & 18 & $>80 \%$ & $55 \%$ & $(57 \pm 23)$ \\
\hline $\mathrm{UVA} / \mathrm{TiO}_{2}-\mathrm{Pd}^{¥}$ & $73 \%^{\mathrm{BeP}}$ & 19 & $>80 \%$ & $29 \%$ & $(70 \pm 15)$ \\
\hline $\mathrm{UVA} / \mathrm{TiO}_{2}-\mathrm{Ag}^{¥}$ & $50 \%$ All & 17 & $>80 \%$ & $21 \%$ & $(61 \pm 9)$ \\
\hline $\mathrm{UVA} / \mathrm{TiO}_{2}-\mathrm{Au}^{¥}$ & $16 \%^{\mathrm{BuP}}$ & 8 & $>80 \%$ & $a b / p$ & $(44 \pm 5)$ \\
\hline $\mathrm{O}_{3} / \mathrm{H}_{2} \mathrm{O}_{2}$ & $100 \%$ & 70 & $57.1 \pm 2.8$ & $29 \%$ & \\
\hline $\mathrm{O}_{3} / \mathrm{UVA}$ & $100 \%$ & 27 & $59.9 \pm 1.8$ & $0 \%$ & $(93 \pm 11)$ \\
\hline $\mathrm{O}_{3} / \mathrm{TiO}_{2}$ & $100 \%$ & 28 & $26.5 \pm 0.5$ & $21 \%$ & $(71 \pm 10)$ \\
\hline $\mathrm{O}_{3} / \mathrm{TiO}_{2}-\mathrm{Pt}$ & $100 \%$ & 35 & $32.9 \pm 1.0$ & $0 \%$ & $(86 \pm 4)$ \\
\hline $\mathrm{O}_{3} / \mathrm{TiO}_{2}-\mathrm{Pd}$ & $100 \%$ & 35 & $33.7 \pm 1.1$ & $15 \%$ & $(90 \pm 3)$ \\
\hline $\mathrm{O}_{3} / \mathrm{TiO}_{2}-\mathrm{Ag}$ & $100 \%$ & 35 & $35.2 \pm 3.9$ & $0 \%$ & $(80 \pm 1)$ \\
\hline $\mathrm{O}_{3} / \mathrm{TiO}_{2}-\mathrm{Au}$ & $100 \%$ & 28 & $31.4 \pm 1.4$ & $0 \%$ & $(71 \pm 5)$ \\
\hline $\mathrm{O}_{3} / \mathrm{UVA} / \mathrm{TiO}_{2}$ & $100 \%$ & 38 & $36.3 \pm 0.0$ & $0 \%$ & $(90 \pm 0)$ \\
\hline $\mathrm{O}_{3} / \mathrm{UVA} / \mathrm{TiO}_{2}-\mathrm{Pt}$ & $100 \%$ & 49 & $61.4 \pm 1.2$ & $0 \%$ & $(107 \pm 11)$ \\
\hline $\mathrm{O}_{3} / \mathrm{UVA} / \mathrm{TiO}_{2}-\mathrm{Pd}$ & $100 \%$ & 41 & $44.2 \pm 1.4$ & $0 \%$ & $(108 \pm 7)$ \\
\hline $\mathrm{O}_{3} / \mathrm{UVA} / \mathrm{TiO}_{2}-\mathrm{Ag}$ & $100 \%$ & 43 & $43.4 \pm 1.4$ & $0 \%$ & $(112 \pm 1)$ \\
\hline $\mathrm{O}_{3} / \mathrm{UVA} / \mathrm{TiO}_{2}-\mathrm{Au}$ & $100 \%$ & 38 & $55.4 \pm 1.0$ & $0 \%$ & $(107 \pm 5)$ \\
\hline
\end{tabular}

For photocatalytic oxidation, the maximum removal is indicated (the paraben considered is given as superscript) $a b / p$ abnormal behaviour and/or paralysis of C. fluminea, $N d$ not determined

*After 60 min of treatment

\# The toxicity after the treatment time was too low to inhibit luminescence

${ }^{¥}$ After 180 min of treatment 
that the photocatalytic oxidation gave the worst results $\left(\mathrm{LI}^{15}\right.$ ${ }^{\mathrm{min}}>80 \%$ ). According to the literature when LI is higher than $80 \%$, the bioassay test is not sensitive to changes, which indicates still very high toxicity towards A. fischeri (MirallesCuevas et al. 2017). Catalytic ozonation gives much better toxicity results than photocatalytic ozonation, despite lower COD removal. This can be related with the by-product production. In fact, Gomes et al. (2019) verified that the presence of hydroxyl radicals for the same paraben mixture in a general way shows more toxicity than the single ozone due to the generation of different by-products.

In the case of Asian clams, for the same conditions, for the initial mixture of parabens, $100 \%$ mortality was achieved after $72 \mathrm{~h}$ of contact. It has to be mentioned that $C$. fluminea is intolerant at the concentration above $7.5 \mathrm{mg} / \mathrm{L}$ of each, and the $\mathrm{LC}_{50}$ of the paraben mixture solution is equal to $56 \%$ (Gomes et al. 2017a). Therefore, for all treatment processes (photolysis, $\mathrm{UVA} / \mathrm{TiO}_{2}$ and $\mathrm{UVA} / \mathrm{TiO}_{2}-\mathrm{Au}$ ) where the degradation was not efficient enough to cause higher concentration, abnormal foot extension and/or paralysis was observed. However, for $\mathrm{TiO}_{2}-\mathrm{Pt}, \mathrm{TiO}_{2}-\mathrm{Ag}$ and $\mathrm{TiO}_{2}-\mathrm{Pd}$, the reduction of paraben toxicity towards $C$. fluminea after the treatment was observed. While after all catalytic ozonation experiments (except for $\mathrm{TiO}_{2}$-Pd- and $\mathrm{Pd}-\mathrm{TiO}_{2}$ ), no mortality was observed. For the samples obtained after photolytic ozonation and photocatalytic ozonation with different photocatalysts, no mortality was verified for all concentrations tested after $72 \mathrm{~h}$ of exposure. The solution after the Fenton process exhibits higher mortality than $\mathrm{O}_{3} / \mathrm{H}_{2} \mathrm{O}_{2}$ and even after single ozonation (29\%).

The high toxic impact of paraben mixture (GI $=(42 \pm$ $11) \%$ ) towards Lepidium sativum was investigated. According to Trautmann and Krasny (1997), this germination index proves strong or severe inhibition, while according to Wang (1992), the inhibition of the root growth of $L$. sativum can be classified as very strong or strong. Almost all treatments increased the phytotoxicity. The photocatalytic oxidation (UVA/TiO $2, \mathrm{UVA} / \mathrm{TiO}_{2}-\mathrm{Au}, \mathrm{UVA} / \mathrm{TiO}_{2}-\mathrm{Pt}$ ) slightly reduced toxicity; however, the inhibition is still strong. After single ozonation $(\mathrm{GI}=(65 \pm 5) \%)$ with $\mathrm{UVA} / \mathrm{TiO}_{2}-\mathrm{Pd}$ and $\mathrm{UVA} / \mathrm{TiO}_{2}-\mathrm{Ag}$ and catalytic ozonation with $\mathrm{TiO}_{2}, \mathrm{TiO}_{2}-\mathrm{Au}$ and $\mathrm{TiO}_{2}-\mathrm{Ag}\left(\mathrm{O}_{3} / \mathrm{TiO}_{2}\right.$ and $\left.\mathrm{O}_{3} / \mathrm{TiO}_{2}-\mathrm{Ag}\right)$, just mild inhibition is observed, which means moderate phytotoxicity. While after $\mathrm{O}_{3} / \mathrm{H}_{2} \mathrm{O}_{2}$ and photocatalytic ozonation with all photocatalysts, no inhibition of plant growth was achieved.

\section{UV dose and cost-effectiveness}

Kinetics was also investigated from the UV fluence point of view (Fig. 7). Following these, the pseudo-first-order degradation rate constants for UV processes were also determined for the curves $\ln \left(C / C_{0}\right)$ (as an average for all paraben
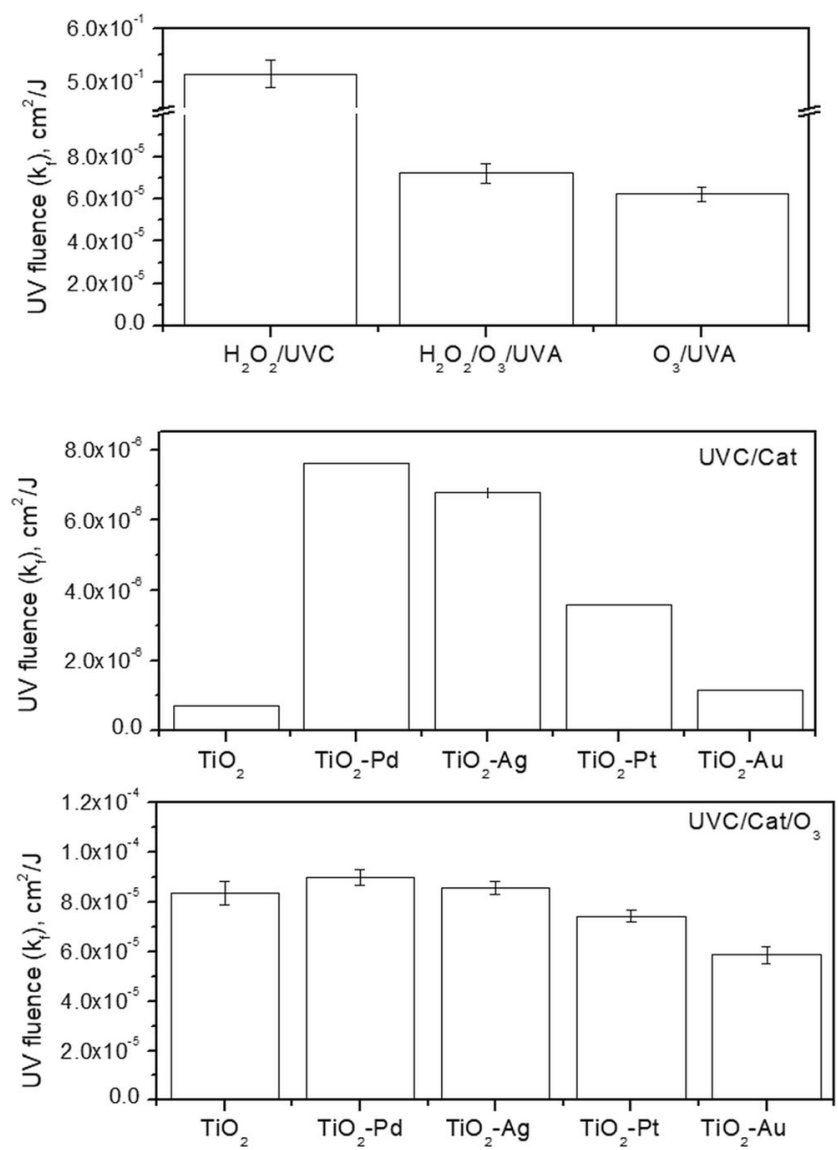

Fig. 7 The obtained pseudo-first-order fluence-based rate constants for paraben mixture degradation by various AOPs

degradations) vs. fluence (not shown), revealing linear correlation coefficients of $0.92-0.98$.

It can be seen that the $\mathrm{H}_{2} \mathrm{O}_{2} / \mathrm{UVC}$ process which was the most effective in paraben decomposition is also the least timeand energy-consuming process. The application of UVA (8.9 $\left.\mathrm{W} / \mathrm{m}^{2}\right)$ instead UVC $\left(31.8 \mathrm{~W} / \mathrm{m}^{2}\right)$, despite the lower lamp power, decreased dramatically $k_{\mathrm{f}}$. Even additional oxidant $\left(\mathrm{O}_{3}\right)$ did not cause the comparable degradation values, proving that $\mathrm{H}_{2} \mathrm{O}_{2} / \mathrm{O}_{3} / \mathrm{UVA}$ and $\mathrm{O}_{3} / \mathrm{UVA}$ are much more energy-consuming. The highest value was obtained for $\mathrm{TiO}_{2}-\mathrm{Pd}[(7.63 \pm$ $3.69) \times 10^{-6} \mathrm{~cm}^{2} / \mathrm{J}$ and $\left.(8.96 \pm 0.34) \times 10^{-5} \mathrm{~cm}^{2} / \mathrm{J}\right]$, for photocatalytic oxidation processes and photocatalytic ozonation, respectively. Also for both processes, $\mathrm{TiO}_{2}-\mathrm{Ag}$ was very effective $\left[(6.80 \pm 0.59) \times 10^{-6} \mathrm{~cm}^{2} / \mathrm{J}\right.$ for $\mathrm{UVA} / \mathrm{TiO}_{2}-\mathrm{Ag}$ and $(8.56 \pm 0.27) \times 10^{-5} \mathrm{~cm}^{2} / \mathrm{J}$ for $\left.\mathrm{UVA} / \mathrm{TiO}_{2}-\mathrm{Ag} / \mathrm{O}_{3}\right]$. For the rest of photocatalysts, the behaviour was different for the case of UVA/Cat and UVA/Cat $/ \mathrm{O}_{3}$. When the photocatalytic oxidation was performed, the $k_{\mathrm{f}}$ value decreases in the following order: $\mathrm{TiO}_{2}-\mathrm{Pt}\left((3.58 \pm 1.63) \times 10^{-6} \mathrm{~cm}^{2} / \mathrm{J}\right)>\mathrm{TiO}_{2}-\mathrm{Au}((1.14$ $\left.\pm 0.23) \times 10^{-6} \mathrm{~cm}^{2} / \mathrm{J}\right)>\mathrm{TiO}_{2}\left((0.72 \pm 0.07) \times 10^{-6} \mathrm{~cm}^{2} / \mathrm{J}\right)$, while for that system where $\mathrm{O}_{3}$ was supplemented, the UV fluence-based pseudo-first-order rate constant for $\mathrm{TiO}_{2}((8.35$ $\left.\pm 0.49) \times 10^{-5} \mathrm{~cm}^{2} / \mathrm{J}\right)$ was higher than that for $\mathrm{TiO}_{2}-\mathrm{Pt}((7.40 \pm$ $\left.0.23) \times 10^{-5} \mathrm{~cm}^{2} / \mathrm{J}\right)>\mathrm{TiO}_{2}-\mathrm{Au}\left((5.84 \pm 0.34) \times 10^{-5} \mathrm{~cm}^{2} / \mathrm{J}\right)$. 
These results indicate that UVA/Cat processes are the most energy-consuming process. Moreover, it was shown that the application of UVA not only increases the time of treatment decreasing mineralisation, which leads to higher energy consumption which determines the treatment costs.

If the application of these methods is to be considered in actual wastewater treatment, the energy cost as well as the operational cost must be known. In this regard, specific energy consumption (SEC) which defines the amount of electrical energy consumption $(\mathrm{kWh})$ per unit mass of COD was calculated (Saien et al. 2014; Shen et al. 2017). When the process was based on the photochemical reaction, Eq. (4) was used (Saien et al. 2014), while in $\mathrm{O}_{3}$-based processes, SEC was calculated according to Eq. (5) (Shen et al. 2017).

$$
\mathrm{SEC}=\frac{P \times t}{V \times\left(\mathrm{COD}_{0}-\mathrm{COD}_{t}\right)}
$$

$\mathrm{SEC}_{\mathrm{O}_{3}}=\frac{P \times t+r \times \mathrm{TOD}}{V \times\left(\mathrm{COD}_{0}-\mathrm{COD}_{t}\right)}$

where $P$ is the nominal electric power $(\mathrm{kW})$ of the photochemical system, $t$ is the reaction time (h), $r$ is the energy requirement for $\mathrm{O}_{3}$ production $\left(15 \mathrm{~kW} \mathrm{~h} / \mathrm{kg} \mathrm{O}_{3}\right.$ ) (Katsoyiannis et al. $2011)$ and $V$ is the volume (L) of the solution in the reactor.

The cost of a treatment from the electricity point of view was found by multiplying the cost of electricity with the SEC value. In the total operational costs of a treatment, several factors were included: oxidants costs, operating costs for ozone production (1.97 €/ $\mathrm{kg} \mathrm{O}_{3}$ (Ried et al. 2009) and costs of catalyst (synthesis and the metal modification).

It can be seen that the lowest SEC was calculated for $\mathrm{O}_{3}$, $\mathrm{O}_{3} / \mathrm{H}_{2} \mathrm{O}_{2}$ and $\mathrm{Cat} / \mathrm{O}_{3}$ due to the lack of requirement of light source application, while for processes UVA/Cat $/ \mathrm{O}_{3}, \mathrm{O}_{3} / \mathrm{H}_{2} \mathrm{O}_{2}$ and $\mathrm{O}_{3} / \mathrm{UVA}$, SEC is 1 order of magnitude lower than that for UVA/Cat and $\mathrm{H}_{2} \mathrm{O}_{2} / \mathrm{UVC}$ (it is obvious that SEC for Sun/Cat is equal to 0 ). Despite the UVA energy consumption for the decomposition, the UVC treatment is much higher in energy
Fig. 8 Total operational costs and specific energy consumption for the applied processes (in lab scale)

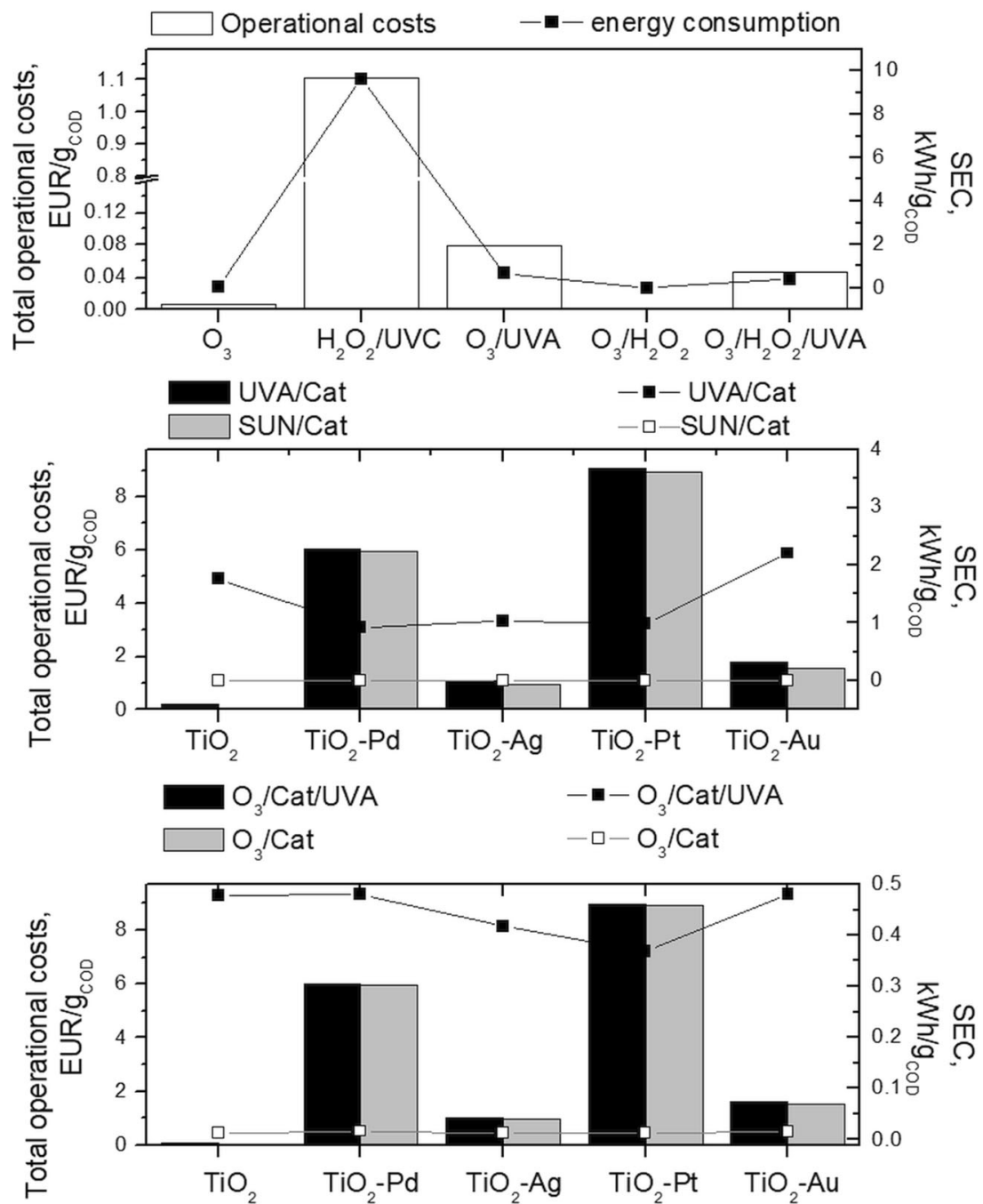


cost. Besides the cost of electricity, there are also expenses for hydrogen peroxide and ozone production. However, the costs of photocatalyst synthesis (especially the cost of noble metals) are predominant in the catalytic process. Despite the highest efficiency, $\mathrm{TiO}_{2}-\mathrm{Pd}$ is characterised by one of the highest operational costs, due to the $\mathrm{Pd}$ price, while for $\mathrm{TiO}_{2}-\mathrm{Ag}$, the costs are positioned around $197 € / g$ COD. In case of those catalysts, the energy consumption is not too high if we consider it from the TOC and COD decrease point of view. The results indicate that the use of $0.42 \mathrm{kWh} / \mathrm{g}$ COD causes $37 \%$ and $43 \%$ of TOC and COD decrease, respectively (Fig. 8, Table S3), which provides a significant and attractive advantage.

\section{Conclusions}

The comparison of several radical-driven technologies for mixture degradation of five parabens was presented. Several AOP methods were examined to degrade parabens from aqueous environment as well as to decrease its toxicity. The ozonation in different process parameters was discussed, bearing in mind that combining ozone with $\mathrm{H}_{2} \mathrm{O}_{2}$, UVA as well as noble metal modified $\mathrm{TiO}_{2}$. The pseudo-first-order kinetic constants (based on time and on UV fluence) were determined. The biodegradability and toxicity assessment has been presented, considering the toxic effect over several species.

For all applied processes, the same trend was observed. The BeP was the fastest degraded paraben, then followed in the order $\mathrm{BuP}>\mathrm{PP}>\mathrm{EP}>\mathrm{MeP}$. The treatments reduced not only COD but also toxicity towards $V$. fischeri, $C$. fluminea and $L$. sativum, despite the fact that the total COD removal was not achieved. This indicates that the refractory byproducts produced are less toxic than parabens.

These results can indicate that the degradation pathway is different, despite the hydroxyl radicals are the main oxidant. The next explanation is that the same TPs formed at the last stage of degradation are in higher concentration. This finding can be with agreement that lower COD removal gives better toxicity results. However, it should be also noticed that the application of pure $\mathrm{TiO}_{2}$ leads to lower toxicity and lower COD removal in comparison to photocatalysts modified by noble metals. Furthermore, from all metals used for $\mathrm{TiO}_{2}$ modification, platinum seems to be the best. Moreover, it is evident that the application of ozone not only improves detoxification, but also higher mineralisation is observed after $\mathrm{O}_{3}$ based treatment.

The results reveal that the treatment efficiency as well as the costs largely depend on the implemented AOP. Nevertheless, the application of hydrogen peroxide, ozone with second oxidant (UVA or $\mathrm{H}_{2} \mathrm{O}_{2}$ ) and $\mathrm{TiO}_{2}$ modified by a noble metal led to much short depletion times when compared with photolysis. Moreover, the synergetic effect not only improved mineralisation and biodegradability but also reduced toxicity and energetic costs.

However, the application of natural sunlight for the photocatalytic oxidation process reduced the cost of lamp equipment as well as electricity, but taking into account the highest mineralisation and biodegradability, the most appropriate cost-effective treatment seems to be photocatalytic ozonation with a UVA lamp. Moreover, detailed characterisation of photocatalysts showed that surface modification of $\mathrm{TiO}_{2}$ with noble metals significantly improved the absorption properties of the catalyst resulting in higher COD abatement from aqueous solutions compared to pure $\mathrm{TiO}_{2}$. This statement was also supported by the width of the band gap of the photocatalysts. The most promising photocatalysts seem to be $\mathrm{TiO}_{2}$ modified by Pd nanoparticles, due to the highest band gap and highest mineralisation. However, when the total operating cost will be taken into account, more reasonable is to use the $\mathrm{TiO}_{2}-\mathrm{Ag}$ that gives satisfactory mineralisation.

Funding information M.G. received financial support from the Mobility Plus (Project No. 1650/MOB/V/2017/0) funded by the Polish Ministry of Science and Higher Education. João Gomes and Rui C. Martins received financial support from Fundação para a Ciência e Tecnologia under the IFCT2014 programme (IF/00215/2014) with financing from the European Social Fund and the Human Potential Operational Programme.

Open Access This article is distributed under the terms of the Creative Commons Attribution 4.0 International License (http:// creativecommons.org/licenses/by/4.0/), which permits unrestricted use, distribution, and reproduction in any medium, provided you give appropriate credit to the original author(s) and the source, provide a link to the Creative Commons license, and indicate if changes were made.

\section{References}

Al Momani F, Sans C, Esplugas S (2004) A comparative study of the advanced oxidation of 2,4-dichlorophenol. J Hazard Mater 107: 123-129. https://doi.org/10.1016/j.jhazmat.2003.11.015

Asgari E, Esrafili A, Rostami R, Farzadkia M (2019) $\mathrm{O}_{3}, \mathrm{O}_{3} / \mathrm{UV}$ and $\mathrm{O}_{3} /$ $\mathrm{UV} / \mathrm{ZnO}$ for abatement of parabens in aqueous solutions: effect of operational parameters and mineralization/biodegradability improvement. Process Saf Environ Prot 125:238-250. https://doi.org/ 10.1016/J.PSEP.2019.03.032

Biń AK (2006) Ozone solubility in liquids. Ozone Sci Eng 28:67-75. https://doi.org/10.1080/01919510600558635

Boczkaj G, Fernandes A (2017) Wastewater treatment by means of advanced oxidation processes at basic $\mathrm{pH}$ conditions: a review. Chem Eng J 320:608-633. https://doi.org/10.1016/j.cej.2017.03.084

Borowska E, Gomes JF, Martins RC et al (2019) Solar photocatalytic degradation of sulfamethoxazole by $\mathrm{TiO}_{2}$ modified with noble metals. Catalysts 9:500. https://doi.org/10.3390/catal9060500

Bumajdad A, Madkour M (2014) Understanding the superior photocatalytic activity of noble metals modified titania under UV and visible light irradiation. Phys Chem Chem Phys 16:7146. https://doi.org/10. 1039/c3cp54411g

Canosa P, Rodríguez I, Rubí E et al (2006) Formation of halogenated byproducts of parabens in chlorinated water. Anal Chim Acta 575: 106-113. https://doi.org/10.1016/J.ACA.2006.05.068 
Esplugas S, Bila DM, Krause LGT, Dezotti M (2007) Ozonation and advanced oxidation technologies to remove endocrine disrupting chemicals (EDCs) and pharmaceuticals and personal care products (PPCPs) in water effluents. J Hazard Mater 149:631-642. https:// doi.org/10.1016/J.JHAZMAT.2007.07.073

Foszpańczyk M, Bednarczyk K, Drozdek E, Martins RC, Ledakowicz S, Gmurek M (2018) Comparison of photocatalytic and photosensitized oxidation of paraben aqueous solutions under sunlight. Water, Air, Soil Pollut 229:362. https://doi.org/10.1007/ s11270-018-3991-y

Giulivo M, Lopez de Alda M, Capri E, Barceló D (2016) Human exposure to endocrine disrupting compounds: their role in reproductive systems, metabolic syndrome and breast cancer. A review. Environ Res 151:251-264. https://doi.org/10.1016/J.ENVRES.2016.07.011

Glaze WH (1986) Reaction products of ozone: a review. Environ Health Perspect 69:151-157

Glaze WH, Kang JW, Chapin DH (1987) The chemistry of water treatment processes involving ozone, hydrogen peroxide and ultraviolet radiation. Ozone Sci Eng 9:335-352

Gmurek M, Rossi AF, Martins RC et al (2015) Photodegradation of single and mixture of parabens - kinetic, by-products identification and cost-efficiency analysis. Chem Eng J 276:303-314. https://doi.org/ 10.1016/j.cej.2015.04.093

Gmurek M, Olak-Kucharczyk M, Ledakowicz S (2017) Photochemical decomposition of endocrine disrupting compounds - a review. Chem Eng J 310:437-456. https://doi.org/10.1016/J.CEJ.2016.05. 014

Gomes J, Pereira JL, Rosa IC et al (2014) Evaluation of candidate biocides to control the biofouling Asian clam in the drinking water treatment industry: an environmentally friendly approach. J Great Lakes Res 40:421-428. https://doi.org/10.1016/j.jglr.2014.03.013

Gomes JF, Bednarczyk K, Gmurek M et al (2017a) Noble metal- $\mathrm{TiO}_{2}$ supported catalysts for the catalytic ozonation of parabens mixtures. Process Saf Environ Prot 111. https://doi.org/10.1016/j.psep.2017. 07.001

Gomes JF, Leal I, Bednarczyk K et al (2017b) Detoxification of parabens using UV-A enhanced by noble metals - $\mathrm{TiO}_{2}$ supported catalysts. J Environ Chem Eng 5:3065-3074. https://doi.org/10.1016/j.jece. 2017.06.010

Gomes JF, Leal I, Bednarczyk K, Gmurek M, Stelmachowski M, Diak M, Emília Quinta-Ferreira M, Costa R, Quinta-Ferreira RM, Martins RC (2017c) Photocatalytic ozonation using doped $\mathrm{TiO}_{2}$ catalysts for the removal of parabens in water. Sci Total Environ 609:329 340. https://doi.org/10.1016/J.SCITOTENV.2017.07.180

Gomes JF, Lopes A, Bednarczyk K et al (2017d) Environmental preservation of emerging parabens contamination: effect of $\mathrm{Ag}$ and $\mathrm{Pt}$ loading over the catalytic efficiency of $\mathrm{TiO}_{2}$ during photocatalytic ozonation. Energy Procedia 136:270-276. https://doi.org/10.1016/J. EGYPRO.2017.10.282

Gomes FER, Bergo PLS, Trap MA, Spadoto M, Galinaro CA, RodriguesFilho E, Leitão A, Tremiliosi-Filho G (2018a) Photolysis of parabens using medium-pressure mercury lamps: toxicity effects in MCF7, Balb/c 3T3 cells and Ceriodaphnia dubia. Chemosphere 208:325-334. https://doi.org/10.1016/J.CHEMOSPHERE.2018. 05.135

Gomes J, Lopes A, Bednarczyk K et al (2018b) Effect of noble metals $\left(\mathrm{Ag}, \mathrm{Pd}, \mathrm{Pt}\right.$ ) loading over the efficiency of $\mathrm{TiO}_{2}$ during photocatalytic ozonation on the toxicity of parabens. Chem Eng 2:4. https:// doi.org/10.3390/chemengineering2010004

Gomes JF, Frasson D, Pereira JL et al (2019) Ecotoxicity variation through parabens degradation by single and catalytic ozonation using volcanic rock. Chem Eng J 360:30-37. https://doi.org/10. 1016/J.CEJ.2018.11.194

Gottschalk C, Libra JA, Saupe A (2010) Ozonation of water and waste water: a practical guide to understanding ozone and its applications. Wiley-VCH
Grabowska E, Marchelek M, Klimczuk T et al (2016) Noble metal modified $\mathrm{TiO}_{2}$ microspheres: surface properties and photocatalytic activity under UV-vis and visible light. J Mol Catal A Chem 423:191206. https://doi.org/10.1016/J.MOLCATA.2016.06.021

Gu MB, Min J, Kim EJ (2002) Toxicity monitoring and classification of endocrine disrupting chemicals (EDCs) using recombinant bioluminescent bacteria. Chemosphere 46:289-294. https://doi.org/10. 1016/S0045-6535(01)00081-9

Haman C, Dauchy X, Rosin C, Munoz J-F (2015) Occurrence, fate and behavior of parabens in aquatic environments: a review. Water Res 68:1-11. https://doi.org/10.1016/J.WATRES.2014.09.030

Hansen KMS, Spiliotopoulou A, Chhetri RK et al (2016) Ozonation for source treatment of pharmaceuticals in hospital wastewater-ozone lifetime and required ozone dose. Chem Eng J 290:507-514. https:// doi.org/10.1016/J.CEJ.2016.01.027

Hashmi MZ, Kumar V, Varma A (2017) Xenobiotics in the soil environment: monitoring, toxicity and management. Springer, Cham

Hoigné J, Bader H (1976) The role of hydroxyl radical reactions in ozonation processes in aqueous solutions. Water Res 10:377-386. https:// doi.org/10.1016/0043-1354(76)90055-5

$\mathrm{Hu}$ X, Bürgi T (2012) Photoinduced electron transfer and photodegradation of malonic acid at $\mathrm{Au} / \mathrm{TiO}$ investigated by in situ ATR-IR spectroscopy. Appl Catal A Gen 449:139-144. https://doi. org/10.1016/J.APCATA.2012.09.017

Ikhlaq A, Muhammad Shahzad Munir H, Khan A et al (2018) Comparative study of catalytic ozonation and Fenton-like processes using iron-loaded rice husk ash as catalyst for the removal of methylene blue in wastewater. Ozone Sci Eng. https://doi.org/10.1080/ 01919512.2018 .1525276

Ikhlaq A, Munir HMS, Khan A et al (2019) Comparative study of catalytic ozonation and Fenton-like processes using iron-loaded rice husk ash as catalyst for the removal of methylene blue in wastewater. Ozone Sci Eng 41:250-260. https://doi.org/10.1080/01919512. 2018.1525276

Jonkers N, Sousa A, Galante-Oliveira S et al (2010) Occurrence and sources of selected phenolic endocrine disruptors in Ria de Aveiro, Portugal. Environ Sci Pollut Res 17:834-843. https://doi.org/10. 1007/s11356-009-0275-5

Juliano C, Magrini G, Juliano C, Magrini GA (2017) Cosmetic ingredients as emerging pollutants of environmental and health concern. A mini-review. Cosmetics 4:11. https://doi.org/10.3390/ cosmetics4020011

Katsoyiannis IA, Canonica S, von Gunten U (2011) Efficiency and energy requirements for the transformation of organic micropollutants by ozone, $\mathrm{O}_{3} / \mathrm{H}_{2} \mathrm{O}_{2}$ and $\mathrm{UV} / \mathrm{H}_{2} \mathrm{O}_{2}$. Water Res 45:3811-3822. https://doi.org/10.1016/J.WATRES.2011.04.038

Lempart A, Kudlek E, Lempart M, Dudziak M (2018) The presence of compounds from the personal care products group in swimming pool water. J Ecol Eng 19:29-37. https://doi.org/10.12911/ 22998993/85377

Leong KH, Chu HY, Ibrahim S, Saravanan P (2015) Palladium nanoparticles anchored to anatase $\mathrm{TiO}_{2}$ for enhanced surface plasmon resonance-stimulated, visible-light-driven photocatalytic activity. Beilstein J Nanotechnol 6:428-437. https://doi.org/10.3762/ bjnano.6.43

Lucas MS, Peres JA, Li Puma G (2010) Treatment of winery wastewater by ozone-based advanced oxidation processes $\left(\mathrm{O}_{3}, \mathrm{O}_{3} / \mathrm{UV}\right.$ and $\mathrm{O}_{3} /$ $\mathrm{UV} / \mathrm{H}_{2} \mathrm{O}_{2}$ ) in a pilot-scale bubble column reactor and process economics. Sep Purif Technol 72:235-241. https://doi.org/10.1016/J. SEPPUR.2010.01.016

Marta-Sanchez AV, Caldas SS, Schneider A, Cardoso SMVS, Primel EG (2018) Trace analysis of parabens preservatives in drinking water treatment sludge, treated, and mineral water samples. Environ Sci Pollut Res 25:14460-14470. https://doi.org/10.1007/s11356-018$1583-4$ 
Martins RC, Gmurek M, Rossi AF, Corceiro V, Costa R, Quinta-Ferreira ME, Ledakowicz S, Quinta-Ferreira RM (2016) Application of Fenton oxidation to reduce the toxicity of mixed parabens. Water Sci Technol 74:1867-1875. https://doi.org/10.2166/wst.2016.374

Mehrjouei M, Müller S, Möller D (2015) A review on photocatalytic ozonation used for the treatment of water and wastewater. Chem Eng J 263:209-219. https://doi.org/10.1016/J.CEJ.2014.10.112

Miklos DB, Remy C, Jekel M, Linden KG, Drewes JE, Hübner U (2018) Evaluation of advanced oxidation processes for water and wastewater treatment - a critical review. Water Res 139:118-131. https://doi. org/10.1016/J.WATRES.2018.03.042

Miralles-Cuevas S, Oller I, Agüera A et al (2017) Strategies for reducing cost by using solar photo-Fenton treatment combined with nanofiltration to remove microcontaminants in real municipal effluents: toxicity and economic assessment. Chem Eng J 318:161-170. https://doi.org/10.1016/J.CEJ.2016.06.031

Nakada N, Shinohara H, Murata A, Kiri K, Managaki S, Sato N, Takada H (2007) Removal of selected pharmaceuticals and personal care products (PPCPs) and endocrine-disrupting chemicals (EDCs) during sand filtration and ozonation at a municipal sewage treatment plant. Water Res 41:4373-4382. https://doi.org/10.1016/J. WATRES.2007.06.038

Nawrocki J, Kasprzyk-Hordern B (2010) The efficiency and mechanisms of catalytic ozonation. Appl Catal B Environ 99:27-42. https://doi. org/10.1016/J.APCATB.2010.06.033

Neyens E, Baeyens J (2003) A review of classic Fenton's peroxidation as an advanced oxidation technique. J Hazard Mater 98:33-50. https:// doi.org/10.1016/S0304-3894(02)00282-0

Olak-Kucharczyk M, Ledakowicz S (2016) How to avoid mass transfer limitations in ozonation kinetics of phenylphenol isomers? Chem Process Eng - Inz Chem i Proces 37:5-13. https://doi.org/10.1515/ cpe-2016-0002

Peng X, Adachi K, Chen C, Kasai H, Kanoh K, Shizuri Y, Misawa N (2006) Discovery of a marine bacterium producing 4hydroxybenzoate and its alkyl esters, parabens. Appl Environ Microbiol 72:5556-5561. https://doi.org/10.1128/AEM.00494-06

Pipolo M, Gmurek M, Corceiro V et al (2017) Ozone-based technologies for parabens removal from water: toxicity assessment. Ozone Sci Eng 39:233-243. https://doi.org/10.1080/01919512.2017.1301246

Ried A, Mielcke J, Wieland A (2009) The potential use of ozone in municipal wastewater. Ozone Sci Eng 31:415-421. https://doi.org/ 10.1080/01919510903199111

Saien J, Osali M, Soleymani AR (2014) UV/persulfate and UV/hydrogen peroxide processes for the treatment of salicylic acid: effect of operating parameters, kinetic, and energy consumption. Desalin Water Treat:1-9. https://doi.org/10.1080/19443994.2014.963156

Salvador P (2007) On the nature of photogenerated radical species active in the oxidative degradation of dissolved pollutants with $\mathrm{TiO}_{2}$ aqueous suspensions: a revision in the light of the electronic structure of adsorbed water. J Phys Chem C 111:17038-17043. https://doi.org/ 10.1021/jp074451i

Shahzad Munir HM, Feroze N, Ikhlaq A et al (2019) Removal of colour and COD from paper and pulp industry wastewater by ozone and combined ozone/UV process. Desalin Water Treat 137:154-161. https://doi.org/10.5004/dwt.2019.23186

Shen W, Wang Y, Zhan J et al (2017) Kinetics and operational parameters for 1,4-dioxane degradation by the photoelectro-peroxone process. Chem Eng J 310:249-258. https://doi.org/10.1016/J.CEJ.2016.10. 111

Soriano-Molina P, García Sánchez JL, Alfano OM et al (2018) Mechanistic modeling of solar photo-Fenton process with $\mathrm{Fe}^{3+}$ EDDS at neutral pH. Appl Catal B Environ 233:234-242. https:// doi.org/10.1016/J.APCATB.2018.04.005

Tay KS, Rahman NA, Abas MRB (2010) Ozonation of parabens in aqueous solution: kinetics and mechanism of degradation. Chemosphere 81:1446-1453. https://doi.org/10.1016/J.CHEMOSPHERE.2010. 09.004

Trautmann NM, Krasny ME (1997) Composting in the classroom: scientific inquiry for high school students. Kendall/Hunt Publishing Company, Dubuque

Vilela CLS, Bassin JP, Peixoto RS (2018) Water contamination by endocrine disruptors: impacts, microbiological aspects and trends for environmental protection. Environ Pollut 235:546-559. https://doi. org/10.1016/j.envpol.2017.12.098

Wang W (1992) Use of plants for the assessment of environmental contaminants. In: In: Ware G.W. (eds) Reviews of Environmental Contamination and Toxicology. Reviews of environmental contamination and toxicology. Springer, New York, pp 87-127

Wang J, Wang S (2016) Removal of pharmaceuticals and personal care products (PPCPs) from wastewater: a review. J Environ Manage 182:620-640. https://doi.org/10.1016/J.JENVMAN.2016.07.049

Wang W-L, Wu Q-Y, Huang N et al (2018) Potential risks from $\mathrm{UV} / \mathrm{H}_{2} \mathrm{O}_{2}$ oxidation and UV photocatalysis: a review of toxic, assimilable, and sensory-unpleasant transformation products. https://doi.org/10. 1016/j.watres.2018.05.005

Wenderich K, Mul G (2016) Methods, mechanism, and applications of photodeposition in photocatalysis: a review. Chem. Rev. 116: $14587-14619$

Wysocka I, Kowalska E, Trzciński K et al (2018) UV-Vis-induced degradation of phenol over magnetic photocatalysts modified with Pt, $\mathrm{Pd}, \mathrm{Cu}$ and $\mathrm{Au}$ nanoparticles. Nanomaterials 8:28. https://doi.org/ 10.3390/nano8010028

Xiao J, Xie Y, Cao H (2015) Organic pollutants removal in wastewater by heterogeneous photocatalytic ozonation. Chemosphere 121:1-17. https://doi.org/10.1016/j.chemosphere.2014.10.072

Yang Y, Ok YS, Kim K-H et al (2017) Occurrences and removal of pharmaceuticals and personal care products (PPCPs) in drinking water and water/sewage treatment plants: a review. Sci Total Environ 596-597:303-320. https://doi.org/10.1016/J. SCITOTENV.2017.04.102

Zielińska-Jurek A (2014) Progress, challenge, and perspective of bimetallic $\mathrm{TiO}_{2}$-based photocatalysts. J Nanomater 2014:1-17. https:// doi.org/10.1155/2014/208920

Publisher's note Springer Nature remains neutral with regard to jurisdictional claims in published maps and institutional affiliations. 